\title{
Pigment signatures of phytoplankton communities in the Beaufort Sea
}

\author{
P. Coupel ${ }^{1}$, A. Matsuoka ${ }^{1}$, D. Ruiz-Pino ${ }^{2}$, M. Gosselin ${ }^{3}$, D. Marie $^{4}$, J.-É. Tremblay ${ }^{1}$, and M. Babin ${ }^{1}$ \\ ${ }^{1}$ Joint International ULaval-CNRS Laboratory Takuvik, Québec-Océan, Département de Biologie, Université Laval, Québec, \\ Québec G1V 0A6, Canada \\ ${ }^{2}$ Laboratoire d'Océanographie et du Climat: Expérimentation et Approches Numériques (LOCEAN), UPMC, CNRS, \\ UMR 7159, Paris, France \\ ${ }^{3}$ Institut des sciences de la mer de Rimouski (ISMER), Université du Québec à Rimouski, 310 allée des Ursulines, Rimouski, \\ Québec G5L 3A1, Canada \\ ${ }^{4}$ Station Biologique, CNRS, UMR 7144, INSU et Université Pierre et Marie Curie, Place George Teissier, \\ 29680 Roscoff, France
}

Correspondence to: P. Coupel (pierre.coupel@takuvik.ulaval.ca)

Received: 11 August 2014 - Published in Biogeosciences Discuss.: 13 October 2014

Revised: 15 December 2014 - Accepted: 30 December 2014 - Published: 17 February 2015

\begin{abstract}
Phytoplankton are expected to respond to recent environmental changes of the Arctic Ocean. In terms of bottom-up control, modifying the phytoplankton distribution will ultimately affect the entire food web and carbon export. However, detecting and quantifying changes in phytoplankton communities in the Arctic Ocean remains difficult because of the lack of data and the inconsistent identification methods used. Based on pigment and microscopy data sampled in the Beaufort Sea during summer 2009, we optimized the chemotaxonomic tool CHEMTAX (CHEMical TAXonomy) for the assessment of phytoplankton community composition in an Arctic setting. The geographical distribution of the main phytoplankton groups was determined with clustering methods. Four phytoplankton assemblages were determined and related to bathymetry, nutrients and light availability. Surface waters across the whole survey region were dominated by prasinophytes and chlorophytes, whereas the subsurface chlorophyll maximum was dominated by the centric diatoms Chaetoceros socialis on the shelf and by two populations of nanoflagellates in the deep basin. Microscopic counts showed a high contribution of the heterotrophic dinoflagellates Gymnodinium and Gyrodinium spp. to total carbon biomass, suggesting high grazing activity at this time of the year. However, CHEMTAX was unable to detect these dinoflagellates because they lack peridinin. In heterotrophic dinoflagellates, the inclusion of the pigments of their prey
\end{abstract}

potentially leads to incorrect group assignments and some misinterpretation of CHEMTAX. Thanks to the high reproducibility of pigment analysis, our results can serve as a baseline to assess change and spatial or temporal variability in several phytoplankton populations that are not affected by these misinterpretations.

\section{Introduction}

The Arctic environment is undergoing transformations caused by climate change highlighted by the accelerating reduction of the summer sea-ice extent (Comiso et al., 2008; Rothrock et al., 1999; Stroeve et al., 2011). Rapid response of phytoplankton in terms of diversity and dominance has already been discussed (Carmack and Wassmann, 2006). A shift towards smaller-sized phytoplankton has been suggested in the Canadian Arctic as a result of low nitrate availability and strong stratification ( $\mathrm{Li}$ et al., 2009). A recent study suggested that nanoflagellates would be promoted in the newly ice-free basins as a consequence of the deepening nitracline (Coupel et al., 2012). More frequent wind-driven upwelling events could multiply the production and favor the development of large taxa such as diatoms (Pickart et al., 2013; Tremblay et al., 2011). The earlier ice retreat may affect the zooplankton and benthos by altering the timing and 
location of the spring bloom and associated species succession (Grebmeier et al., 2010; Hunt Jr. et al., 2002). In response to these changes, a reorganization of the Arctic Ocean food web would be expected causing changes in the function of the ecosystem and ultimately fisheries, but also in biogeochemical cycles (Falkowski, 2000) and carbon export (Sigman and Boyle, 2000; Wassmann and Reigstad, 2011).

Monitoring the diversity and dominance of Arctic phytoplankton is a prerequisite for documenting change. However, it is very difficult to detect responses of phytoplankton in the Arctic due to a lack of quantitative information on taxonomic composition (Poulin et al., 2010; Wassmann et al., 2011). The various approaches used for phytoplankton identification greatly increased the breadth of knowledge on phytoplankton communities but limit the possibility of intercomparisons between different data sets. In the aim to detect year-to-year main changes in the phytoplankton communities, a reproducible method needs to be established. Optical microscopy is a good option to identify and enumerate large phytoplankton but the procedure is expensive, time-consuming and relies greatly on the skill of the taxonomist (Wright and Jeffrey, 2006). Flow cytometry and molecular analyses are better suited to identify small phytoplankton (Ansotegui et al., 2001; Roy et al., 1996; Schlüter et al., 2000). The remote sensing approach is becoming increasingly attractive with the recent advances in the interpretation of optical signals to detect diatoms and other phytoplankton groups from space (Alvain et al., 2005; Hirata et al., 2011; Sathyendranath et al., 2004; Uitz et al., 2006). But these approaches, developed with in situ data set from non-polar regions, still need to be adapted and tuned for the Arctic region. However, the satellite method is restricted to the surface layer and is still limited by the presence of sea ice, frequent cloudy conditions and coastal turbidity in the Arctic Ocean (IOCCG, 2014).

The use of pigments as markers of major phytoplankton groups is a good candidate for monitoring Arctic phytoplankton although it is limited by the acquisition of water samples during oceanographic cruises. Automated measurements of pigment concentrations using high-performance liquid chromatography (HPLC) allows fast and highly reproducible analysis (Jeffrey et al., 1997). Moreover, pigment analysis allows for the characterization of both the large and small size phytoplankton (Hooker et al., 2005). The main issue when using pigments for quantitative taxonomy is the overlap of several pigments among phytoplankton groups. The chemotaxonomic software CHEMTAX (CHEMical TAXonomy) was developed to overcome this problem by considering a large suite of pigments simultaneously (Mackey et al., 1996). CHEMTAX has been widely used in the global ocean, notably in Antarctic polar waters (Kozlowski et al., 2011; Rodriguez et al., 2002; Wright et al., 1996).

Only few studies have used CHEMTAX in the Arctic Ocean to date. Spatial and temporal variability of the phy- toplankton community structure was described for the North Water Polynya (Vidussi et al., 2004) and the Canada Basin (Coupel et al., 2012; Taylor et al., 2013), while Alou-Font et al. (2013) used CHEMTAX to describe the influence of snow conditions on the sea-ice communities of Amundsen Gulf. Phytoplankton communities were also investigated using CHEMTAX in subarctic regions, i.e., the Bering Sea (Suzuki et al., 2002) and in the Faroe-Shetland channel (Riegman and Kraay, 2001). Investigations of the reliability of CHEMTAX underscores the need to adapt procedures to the targeted area by investigating the dominant species, their pigment content and the environmental conditions such as light availability and nutrient status (Wright and Jeffrey, 2006). Despite this caveat, most prior studies using CHEMTAX in the Arctic Ocean have used a parameterization made for Antarctic waters. Inappropriate parameterization of CHEMTAX has been identified as the main source of misinterpretation in taxonomic determination based on pigments (Irigoien et al., 2004; Lewitus et al., 2005). Knowing this, a regional parameterization of CHEMTAX is required before using it to examine possible changes in the phytoplankton community structure. Then, regional settings could be used as a starting point for other Arctic CHEMTAX work.

The objective of this study was to examine Arctic phytoplankton community structure with CHEMTAX using samples collected during summer in the Beaufort Sea. This region, which is influenced by freshwater from the Mackenzie River over the narrow continental shelf and by oceanic and ice-melt waters in the deep ocean basin, allowed us to test the performance of CHEMTAX under diverse environmental conditions. Accurate taxonomic identification and enumeration of cells $>3 \mu \mathrm{m}$ were combined with flow-cytometric sorting and counting of picophytoplankton cells $(1-3 \mu \mathrm{m})$ to identify the dominant phytoplankton groups. The pigment ratios of these dominant Arctic groups were then found in the literature and used to tune the CHEMTAX software for the Beaufort Sea region. This work demonstrates the use of CHEMTAX to describe phytoplankton populations, and similar studies conducted in the future could be used to investigate changes in populations over time.

\section{Materials and methods}

Hydrographical observations and seawater sampling were carried out in the Beaufort Sea $\left(69-73^{\circ} \mathrm{N} ; 125-145^{\circ} \mathrm{W}\right)$ during Leg $2 b$ of the MALINA cruise in summer 2009 (30 July to 27 August 2009) onboard the CCGS Amundsen. Twenty stations were sampled on the Mackenzie shelf and the deep waters of the Beaufort Sea (Fig. 1) using Niskintype bottles mounted on a CTD (Conductivity, Temperature, Depth)-Rosette system equipped with sensors to measure photosynthetically active radiation (PAR; Biospherical QCP2300), temperature and salinity (Sea-Bird SBE-911plus). Phytoplankton communities were investigated using three 


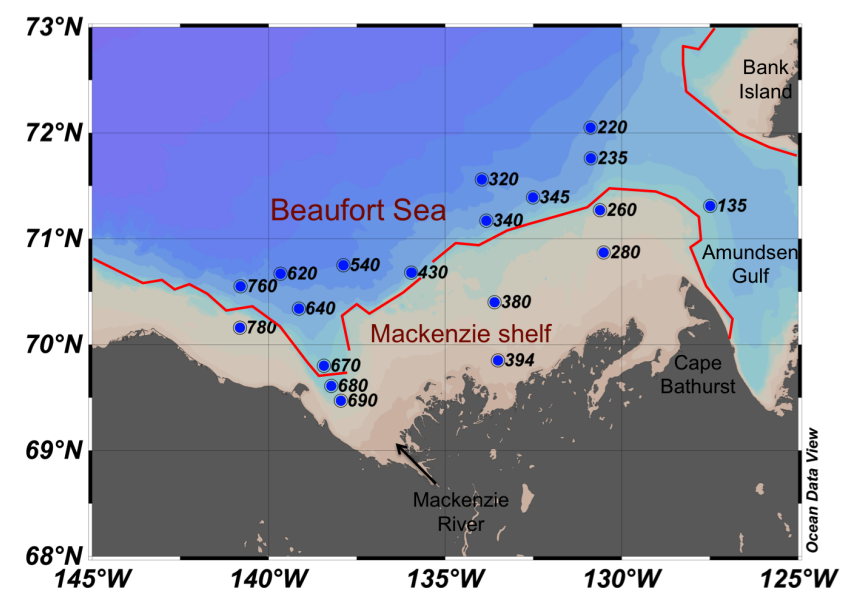

Figure 1. Location of the sampling stations in the Canadian Beaufort Sea from 30 July to 27 August 2009 during the MALINA expedition. The isobath $150 \mathrm{~m}$ (in red) separates the Mackenzie shelf from the deep waters of the Beaufort Sea.

different approaches: pigment signature (386 samples), light microscopy (88 samples) and flow cytometry (182 samples).

\subsection{Pigments}

We followed the HPLC analytical procedure proposed by Van Heukelem and Thomas (2001). Briefly, photosynthetic phytoplankton pigments were sampled at 6-10 depths at different sites in the upper $200 \mathrm{~m}$ of the water column, however only samples from the surface $(5 \mathrm{~m})$ and subsurface chlorophyll $a$ maximum (SCM) are presented in this work. Seawater aliquots ranging from 0.25 to $2.27 \mathrm{~L}$ were filtered through $25 \mathrm{~mm}$ Whatman GF/F filters (nominal pore size of $0.7 \mu \mathrm{m}$ ) and frozen immediately at $-80^{\circ} \mathrm{C}$ in liquid nitrogen until analysis. Analyses were performed at the Laboratoire d'Océanographie de Villefranche (LOV). Filters were extracted in $3 \mathrm{~mL}$ methanol $(100 \%)$ for $2 \mathrm{~h}$, disrupted by sonication, centrifuged and filtered (Whatman $\mathrm{GF} / \mathrm{F}$ ). The extracts were injected within $24 \mathrm{~h}$ onto a reversed phase C8 Zorbax Eclipse column (dimensions: $3 \times 150 \mathrm{~mm}$; $3.5 \mu \mathrm{m}$ pore size). Instrumentation comprised an Agilent Technologies 1100 series HPLC system with diode array detection at $450 \mathrm{~nm}$ (carotenoids and chlorophyll $c$ and $b$ ), $676 \mathrm{~nm}$ (chlorophyll $a$ and derivatives) and $770 \mathrm{~nm}$ (bacteriochlorophyll $a$ ). The concentrations of 21 pigments, including chlorophyll $a(\mathrm{Chl} a)$, were obtained and used in this study (see Table 1 for details and pigment abbreviations). The limits of detection $(3 \times$ noise $)$ for the different pigments, based on a filtered volume of $2 \mathrm{~L}$, ranged from 0.0001 to $0.0006 \mathrm{mg} \mathrm{m}^{-3}$. The precision of the instrument was tested using injected standards and showed a variation coefficient of $0.35 \%$. Moreover, previous tests of the precision of the instrument and method used here were conducted on field samples replicates. A coefficient of variation of 3.2 and $4 \%$ was found for the primary and secondary pigment, respectively. Such precision was in accordance with the $3 \%$ standard high precision required in the analysis of field samples (Hooker et al., 2005).

\subsection{Light microscopy and flow cytometry}

One to six depths at different sites were sampled in the upper $100 \mathrm{~m}$ of the water column for taxonomic identification and enumeration of phytoplankton cells by light microscopy. Samples were preserved in acidic Lugol's solution and stored in the dark at $4{ }^{\circ} \mathrm{C}$ until analysis. The counting of cells $>3 \mu \mathrm{m}$ was performed using an inverted microscope (Wild Heerbrugg and Zeiss Axiovert 10) following the Utermöhl method with settling columns of 25 and $50 \mathrm{~mL}$ (Lund et al., 1958). A minimum of 400 cells were counted over at least three transects. Autotrophic and heterotrophic protists were counted. The autotrophic phytoplankton were distributed among 10 classes plus a group of unidentified flagellates (Table 2). Unidentified cells $(>3 \mu \mathrm{m})$ represented less than $10 \%$ of the total cell abundance over the shelf but reached $75 \%$ of the total cell abundance over the basin. Half of the unidentified cells were smaller than $5 \mu \mathrm{m}$. Enumeration of picophytoplankton $(1-3 \mu \mathrm{m})$ by flow cytometry analysis (Marie et al., 1997) was performed onboard using a FACSAria (Becton Dickinson, San Jose, CA, USA) and following the method described in Balzano et al. (2012).

\subsection{Converting abundance to carbon biomass}

Phytoplankton abundances obtained by light microscopy and flow cytometry were converted into carbon biomass (Table 2). The carbon biomass $\left(C, \mathrm{ng} \mathrm{Cm}^{-3}\right)$ is obtained by multiplying cell abundance $\left(A\right.$, cells $\left.\mathrm{L}^{-1}\right)$ by mean cellular carbon content (CC, ng $\mathrm{C}$ per cell) for each phytoplankton group:

$C=A \cdot \mathrm{CC}$,

where $\mathrm{CC}$ was derived from cell biovolume $\left.\left(\mathrm{BV} ; \mu^{3}\right)^{3}\right)$ using three conversion equations determined by regression analysis on a large data set (Menden-Deuer and Lessard, 2000). Diatoms and dinoflagellates require particular formulas because of their low (diatoms) or high (dinoflagellates) specific carbon content relative to other protists:

- Diatoms: $\mathrm{CC}=0.288 \times \mathrm{BV}^{0.811}$,

- Dinoflagellates: $\mathrm{CC}=0.760 \times \mathrm{BV}^{0.819}$,

- All other protists (except diatoms and dinoflagellates): $\mathrm{CC}=0.216 \times \mathrm{BV}^{0.939}$,

where species BV were compiled from Olenina et al. (2006). When species BV were not referenced, biovolumes were estimated according to cell shape and dimensions (BérardTherriault et al., 1999) using appropriate geometric formulas 
Table 1. Distribution of major taxonomically significant pigments in algal classes using SCOR (Scientific Council for Oceanic Research) abbreviations (Jeffrey et al., 1997).

\begin{tabular}{|c|c|c|}
\hline Pigment & Abbreviation & Specificity \\
\hline \multicolumn{3}{|l|}{ Chlorophyll } \\
\hline Chlorophyll $a$ & Chl $a$ & All photosynthetic algae \\
\hline Bacteriochlorophyll $a$ & BChl $a$ & Photosynthetic bacteria \\
\hline Chlorophyll $b$ & Chl $b$ & Dominant in green algae \\
\hline Chlorophyll $c_{1}+c_{2}$ & $\mathrm{Chl} c_{1}+c_{2}$ & Minor in red algae \\
\hline Chlorophyll $c_{3}$ & $\mathrm{Chl} c_{3}$ & Dominant in haptophyte, many diatoms and some dinoflagellates \\
\hline Chlorophyllide $a$ & Chlide $a$ & Degradation products of chlorophyll $a$ \\
\hline Pheophorbide $a$ & Pheide $a$ & Degradation products of chlorophyll $a$ \\
\hline Pheophytin $a$ & Phe $a$ & Degradation products of chlorophyll $a$ \\
\hline Carotene(s) & Car & Dominant in chlorophytes, prasinophytes, minor in all other algal groups \\
\hline \multicolumn{3}{|r|}{$e^{2}$} \\
\hline Alloxanthine & Allo & Major in Cryptophytes \\
\hline 19'-butanoyloxyfucoxanthin & But-fuco & Dominant in pelagophytes, dictyochophytes. Present in some haptophytes \\
\hline Diadinoxanthin & Diadino & Diatoms, haptophytes, pelagophytes, dictyochophytes and some dinoflagellates \\
\hline Diatoxanthin & Diato & Diatoms, haptophytes, pelagophytes, dictyochophytes and some dinoflagellates \\
\hline Fucoxanthin & Fuco & Dominant in most red algae \\
\hline 19'-hexanoyloxyfucoxanthin & Hex-fuco & Major in Haptophytes and dinoflagellates Type 2* (lacking Peridinin) \\
\hline Lutein & Lut & Chlorophytes, prasinophytes \\
\hline Neoxanthin & Neo & Chlorophytes, prasinophytes \\
\hline Peridinin & Peri & Dinoflagellates Type $1^{*}$ \\
\hline Prasinoxanthin & Pras & Prasinophytes Types 3A and 3B \\
\hline Violaxanthin & Viola & Dominant in chlorophytes, prasinophytes, chrysophytes, some dinoflagellates \\
\hline Zeaxanthin & Zea & Dominant in cyanobacteria, pelagophytes, chrysophytes, some dinoflagellates \\
\hline
\end{tabular}

* Higgins et al. (2011).

(Olenina et al., 2006). Replicate measurements of the diameter of some common diatom and dinoflagellate species shows a variability in the biovolume around $30 \%$ (Menden-Deuer and Lessard, 2000; Olenina et al., 2006). A $30 \%$ overestimation of the biovolume of a species would cause a 20 to $30 \%$ overestimation of its carbon biomass depending on the conversion equation used.

According to the three conversion equations, a large-sized dinoflagellate $\left(\mathrm{BV}=10000 \mu \mathrm{m}^{3}\right)$ contains 3 times more carbon than a diatom of the same biovolume and $15 \%$ more carbon than a protist of the same biovolume. However, in the case of a small cell volume $\left(\mathrm{BV}=10 \mu \mathrm{m}^{3}\right)$, a dinoflagellate would contain 2.5 times more carbon than both a diatom and a protist.

\subsection{Pigment interpretation: CHEMTAX}

The CHEMTAX method (Mackey et al., 1996) was used to estimate the algal class biomass from measurements of in situ pigment. Two inputs are required to create the ratio matrix used to run the CHEMTAX program: the major phytoplankton groups present in our study area (chemotaxonomic classes) and their pigment content expressed as initial "pigment / TChl $a$ " ratios where TChl $a$ is the total Chl $a$ concentration, i.e., the sum of Chl $a$ and chlorophyllide $a$ (Chlide $a$, Table 3a).
The algal groups identified by microscopy were grouped in nine chemotaxonomic classes. The very high dominance of the centric diatom Chaetoceros socialis in several stations over the shelf allowed us to accurately define the pigment / TChl $a$ ratios of the diatom class. For the other phytoplankton groups, due to the fact that their specific pigment signatures, we used the pigment / TChl $a$ ratios from the literature. Then, we chose the ratios representative of the dominant species associated with each chemotaxonomic class previously identified with microscopy. The dinoflagellate class represents the dinoflagellates containing peridinin (Peri) as Heterocapsa rotundata whose ratio Peri / TChl $a$ was set to 0.6 (Vidussi et al., 2004). The $c_{3}$-flagellates group corresponds to the Dino-2 class defined in Higgins et al. (2011), which included the dinoflagellates type 2 lacking pigment peridinin. We chose here to replace the group name Dino2 with $c_{3}$-flagellates because we think the characteristics of this groups, i.e., a relatively high chlorophyll $c_{3}\left(\mathrm{Chl} c_{3}\right)$ concentration relative to their 19'-butanoyloxyfucoxanthin (Butfuco) and 19'- hexanoyloxyfucoxanthin (Hex-fuco) concentrations, included a larger diversity of flagellates including raphidophytes and dictyochophytes and dictyochophytes in addition to the autotrophic dinoflagellates lacking Peri. The cryptophytes were detected by the presence of alloxanthin (Allo) pigment. The haptophytes type 7 class refers to the prymnesiophyte-type Chrysochromulina spp. discriminated 
Table 2. Abundance and carbon biomass (mean \pm SD) of the major protist groups in surface and subsurface chlorophyll $a$ maximum (SCM) depth of the Mackenzie shelf and in deep waters of the Beaufort Sea. The mean percent contribution of each protist group to the total cell abundance and total carbon biomass is indicated in parentheses. Large $(>3 \mu \mathrm{m})$ and small $(<3 \mu \mathrm{m})$ cells were counted by light microscopy and flow cytometry, respectively. The average cell abundance and carbon biomass are in bold characters. Total chlorophyll $a$ concentration (mean \pm standard) is indicated at the bottom of the table. The heterotrophic group is composed of flagellated protozoans.

\begin{tabular}{|c|c|c|c|c|}
\hline \multirow[b]{2}{*}{ Number of stations } & \multicolumn{2}{|c|}{ Mackenzie Shelf } & \multicolumn{2}{|c|}{ Beaufort Sea } \\
\hline & $\begin{array}{l}\text { Surface }(3 \mathrm{~m}) \\
\quad N=8\end{array}$ & $\begin{array}{c}\mathrm{SCM}(35 \pm 8 \mathrm{~m}) \\
N=6\end{array}$ & $\begin{array}{l}\text { Surface }(3 \mathrm{~m}) \\
\quad N=13\end{array}$ & $\begin{array}{c}\mathrm{SCM}(61 \pm 7 \mathrm{~m}) \\
N=13\end{array}$ \\
\hline Total abundance (cells mL ${ }^{-1}$ ) & $4500 \pm 1400$ & $4000 \pm 1500$ & $4400 \pm 1400$ & $2500 \pm 2500$ \\
\hline Algae $>3 \mu \mathrm{m}$ & $660 \pm 830(15.0)$ & $3000 \pm 900(74.1)$ & $140 \pm 140(3.2)$ & $93 \pm 110(3.8)$ \\
\hline Diatoms & $410 \pm 610(61.2)$ & $2900 \pm 790(97.5)$ & $7.1 \pm 5.7(5)$ & $8 \pm 11(8.5)$ \\
\hline Dinoflagellates & $44 \pm 30(6.6)$ & $8.4 \pm 4.8(0.3)$ & $19 \pm 15(13.1)$ & $11 \pm 5(11.9)$ \\
\hline Chlorophytes & $0.6 \pm 0.9(0.1)$ & $0.1 \pm 0.3(0)$ & $0.2 \pm 0.4(0.1)$ & $0.0 \pm 0.1(0)$ \\
\hline Chrysophytes & $36 \pm 39(5.4)$ & $4.9 \pm 10.0(0.2)$ & $5.4 \pm 6.3(3.8)$ & $0.1 \pm 0.2(0.1)$ \\
\hline Dictyochophytes & $18 \pm 28(2.6)$ & $0.7 \pm 1.7(0)$ & $9.5 \pm 9.4(6.7)$ & $0.5 \pm 0.9(0.5)$ \\
\hline Cryptophytes & $19 \pm 23(2.8)$ & $5.6 \pm 7.0(0.2)$ & $4.6 \pm 5.2(3.3)$ & $7 \pm 20(7.4)$ \\
\hline Euglenophytes & $0.2 \pm 0.4(0)$ & $0.1 \pm 0.1(0)$ & $0.2 \pm 0.5(0.1)$ & $0.1 \pm 0.1(0.1)$ \\
\hline Prasinophytes & $21 \pm 27(3.2)$ & $0.4 \pm 0.4(0)$ & $30 \pm 38(21.2)$ & $0.7 \pm 1.5(0.8)$ \\
\hline Prymnesiophytes & $15 \pm 25(2.3)$ & $4.0 \pm 5.5(0.1)$ & $19 \pm 22(13.7)$ & $22 \pm 25(24.3)$ \\
\hline Unidentified flagellates & $100 \pm 40(15.7)$ & $48 \pm 36(1.6)$ & $46 \pm 33(32.8)$ & $37 \pm 41(39.9)$ \\
\hline Raphidophytes & $0 \pm 0(0)$ & $0.5 \pm 0.5(0)$ & $0.0 \pm 0.1(0)$ & $6.0 \pm 6.2(6.5)$ \\
\hline Algae $<3 \mu \mathrm{m}$ & $3600 \pm 1500(81.2)$ & $930 \pm 850(23.5)$ & $4000 \pm 1200(91.7)$ & $2200 \pm 1300(91.1)$ \\
\hline Heterotrophs $>3 \mu \mathrm{m}$ & $40 \pm 60(0.9)$ & $12 \pm 14(0.3)$ & $27 \pm 39(0.6)$ & $2.7 \pm 2.4(0.1)$ \\
\hline Unidentified cells $>3 \mu \mathrm{m}$ & $120 \pm 120(2.8)$ & $86 \pm 44(2.2)$ & $190 \pm 270(4.4)$ & $120 \pm 160(5.0)$ \\
\hline Total biomass $\left(\mathrm{mg} \mathrm{C} \mathrm{m}^{-3}\right)$ & $64 \pm 22$ & $110 \pm 57$ & $25 \pm 7$ & $14 \pm 5$ \\
\hline Algae $>3 \mu \mathrm{m}$ & $43 \pm 40(54.7)$ & $100 \pm 46(86.8)$ & $12 \pm 10(39.5)$ & $9.2 \pm 7.6(48.5)$ \\
\hline Diatoms & $15 \pm 17(35.9)$ & $91 \pm 40(89.2)$ & $0.51 \pm 0.37(5)$ & $0.31 \pm 0.53(3.8)$ \\
\hline Dinoflagellates & $23 \pm 20(56.7)$ & $9.7 \pm 4.8(9.5)$ & $7.93 \pm 6.49(76.9)$ & $4.63 \pm 3.22(57.3)$ \\
\hline Chlorophytes & $0.10 \pm 0.21(0.3)$ & $0.00 \pm 0.00(0)$ & $0.04 \pm 0.11(0.4)$ & $0.00 \pm 0.01(0)$ \\
\hline Chrysophytes & $0.48 \pm 0.33(1.2)$ & $0.09 \pm 0.18(0.1)$ & $0.32 \pm 0.62(3.2)$ & $0.00 \pm 0.01(0)$ \\
\hline Dictyochophytes & $0.15 \pm 0.24(0.4)$ & $0.01 \pm 0.03(0)$ & $0.09 \pm 0.09(0.9)$ & $0.00 \pm 0.01(0)$ \\
\hline Cryptophytes & $0.28 \pm 0.33(0.7)$ & $0.29 \pm 0.45(0.3)$ & $0.04 \pm 0.05(0.4)$ & $0.03 \pm 0.06(0.4)$ \\
\hline Euglenophytes & $0.04 \pm 0.06(0.1)$ & $0.02 \pm 0.04(0)$ & $0.07 \pm 0.16(0.7)$ & $0.14 \pm 0.36(1.7)$ \\
\hline Prasinophytes & $0.31 \pm 0.35(0.8)$ & $0.01 \pm 0.01(0)$ & $0.49 \pm 0.60(4.8)$ & $0.02 \pm 0.04(0.2)$ \\
\hline Prymnesiophytes & $0.13 \pm 0.19(0.3)$ & $0.04 \pm 0.05(0)$ & $0.19 \pm 0.21(1.9)$ & $0.36 \pm 0.53(4.5)$ \\
\hline Unidentified flagellates & $1.52 \pm 0.60(3.7)$ & $0.57 \pm 0.30(0.6)$ & $0.60 \pm 0.40(5.8)$ & $0.48 \pm 0.45(6)$ \\
\hline Raphidophytes & $0 \pm 0(0)$ & $0.29 \pm 0.29(0.3)$ & $0.01 \pm 0.02(0.1)$ & $2.10 \pm 1.68(26)$ \\
\hline Algae $<3 \mu \mathrm{m}$ & $1.9 \pm 0.8(2.4)$ & $0.49 \pm 0.45(0.4)$ & $2.1 \pm 0.7(6.7)$ & $1.2 \pm 0.7(6.2)$ \\
\hline Heterotrophs $>3 \mu \mathrm{m}$ & $15 \pm 24(19.3)$ & $5.4 \pm 5.6(4.6)$ & $6.3 \pm 10.6(20.2)$ & $1.0 \pm 1.2(5.3)$ \\
\hline Unidentified cells $>3 \mu \mathrm{m}$ & $3.8 \pm 4.0(4.9)$ & $2.3 \pm 2.1(2.0)$ & $4.0 \pm 4.4(12.9)$ & $2.9 \pm 3.6(15.4)$ \\
\hline Total Chlorophyll $a\left(\mathrm{mg} \mathrm{m}^{-3}\right)$ & $0.20 \pm 0.13$ & $2.84 \pm 2.55$ & $0.10 \pm 0.09$ & $0.31 \pm 0.17$ \\
\hline
\end{tabular}

by a high ratio of Hex-fuco to TChl $a$. In contrast, the chrysophytes and pelagophytes contained a high ratio of Butfuco to TChl $a$. Finally, three groups of green algae containing chlorophyll $b(\mathrm{Chl} b)$ were considered: chlorophytes, prasinophytes type 2 and prasinophytes type 3 . The prasinophytes type 3 containing the pigments prasinoxanthin (Pras) is representative of the pico-sized Micromonas sp. while the type 2 is associated with prasinophytes lacking Pras such as the nano-sized Pyramimonas sp. Chlorophytes were evidenced by significant concentrations of lutein (Lut), a char- acteristic pigment of this group (Del Campo et al., 2000). The effect of light levels on pigment ratios was taken into account by considering two ratio matrices, a high light ratio matrix runs on surface samples $(0-20 \mathrm{~m})$ and low light ratio matrix runs on subsurface samples (20-200 m). Moreover, photoprotective carotenoids (PPC $=$ diadinoxanthin (Diadino) + diatoxanthin (Diato) + zeaxanthin (Zea) + violaxanthin (Viola) + carotenes (Car)) were not used since they varied strongly with irradiance and/or they are taxonomically widespread (Demers et al., 1991). Finally, we carried out 
Table 3. Pigment : TChl $a$ ratios for each algal group under low (SCM samples) and high light (surface samples) light levels. (A) Initial ratio matrix determined from ${ }^{\mathrm{a}}$ this study, ${ }^{\mathrm{b}}$ Vidussi et al. (2004), ${ }^{\mathrm{c}}$ Higgins et al. (2011); (B) final ratio matrix obtained after CHEMTAX recalculation in order to find the best fit between the in situ pigment concentrations and our initial ratio matrix. The symbol "-” indicates similar ratios between low and high light levels. Pigment abbreviations are defined in Table 1. According to Higgins et al. (2011): ChrysoPelago: Chrysophytes and Pelagophytes; Hapto-7: haptophytes type 7; Prasino-3: prasinophytes type 3; Prasino-2: prasinophytes type 2.

\begin{tabular}{|c|c|c|c|c|c|c|c|c|c|c|c|c|}
\hline Class / Pigment & Light & $\mathrm{Chl} c_{3}$ & Chl $c_{1+2}$ & But-fuco & Fuco & Hex-fuco & $\mathrm{Neo}$ & Pras & Chl $b$ & Allo & Lut & Peri \\
\hline \multicolumn{13}{|c|}{ (A) Initial ratio matrix } \\
\hline \multirow[t]{2}{*}{${ }^{\mathrm{a}}$ Diatoms } & Low & 0 & 0.171 & 0 & 0.425 & 0 & 0 & 0 & 0 & 0 & 0 & 0 \\
\hline & High & 0 & 0.192 & 0 & 0.495 & 0 & 0 & 0 & 0 & 0 & 0 & 0 \\
\hline \multirow[t]{2}{*}{${ }^{\mathrm{b}}$ Dinoflagellate } & Low & 0 & 0 & 0 & 0 & 0 & 0 & 0 & 0 & 0 & 0 & 0.6 \\
\hline & High & 0 & 0 & 0 & 0 & 0 & 0 & 0 & 0 & 0 & 0 & 0.6 \\
\hline \multirow[t]{2}{*}{${ }^{\mathrm{c}} c_{3}$-flagellates } & Low & 0.262 & 0.144 & 0.07 & 0.226 & 0.101 & 0 & 0 & 0 & 0 & 0 & 0 \\
\hline & High & 0.179 & 0.126 & 0.081 & 0.3 & 0.194 & 0 & 0 & 0 & 0 & 0 & 0 \\
\hline \multirow[t]{2}{*}{${ }^{\mathrm{c}}$ Cryptophytes } & Low & 0 & 0.104 & 0 & 0 & 0 & 0 & 0 & 0 & 0.277 & 0 & 0 \\
\hline & High & 0 & - & 0 & 0 & 0 & 0 & 0 & 0 & 0.211 & 0 & 0 \\
\hline \multirow[t]{2}{*}{${ }^{\mathrm{b}}$ Chryso-Pelago } & Low & 0.114 & 0.285 & 0.831 & 0.337 & 0 & 0 & 0 & 0 & 0 & 0 & 0 \\
\hline & High & - & 0.316 & 1.165 & 0.425 & 0 & 0 & 0 & 0 & 0 & 0 & 0 \\
\hline \multirow[t]{2}{*}{${ }^{\mathrm{c}}$ Hapto-7 } & Low & 0.171 & 0.276 & 0.013 & 0.259 & 0.491 & 0 & 0 & 0 & 0 & 0 & 0 \\
\hline & High & 0.215 & 0.236 & 0.023 & 0.42 & 0.682 & 0 & 0 & 0 & 0 & 0 & 0 \\
\hline \multirow[t]{2}{*}{${ }^{\mathrm{c}}$ Prasino-2 } & Low & 0 & 0 & 0 & 0 & 0 & 0.033 & 0 & 0.812 & 0 & 0.096 & 0 \\
\hline & High & 0 & 0 & 0 & 0 & 0 & 0.056 & 0 & 0.786 & 0 & 0.038 & 0 \\
\hline \multirow[t]{2}{*}{${ }^{\mathrm{c}}$ Prasino-3 } & Low & 0 & 0 & 0 & 0 & 0 & 0.078 & 0.248 & 0.764 & 0 & 0.009 & 0 \\
\hline & High & 0 & 0 & 0 & 0 & 0 & 0.116 & 0.241 & 0.953 & 0 & 0.008 & 0 \\
\hline \multirow[t]{2}{*}{${ }^{\mathrm{c}}$ Chlorophytes } & Low & 0 & 0 & 0 & 0 & 0 & 0.036 & 0 & 0.339 & 0 & 0.187 & 0 \\
\hline & High & 0 & 0 & 0 & 0 & 0 & 0.029 & 0 & 0.328 & 0 & 0.129 & 0 \\
\hline \multicolumn{13}{|c|}{ (B) Final ratio matrix } \\
\hline \multirow[t]{2}{*}{${ }^{\text {a} D i a t o m s ~}$} & Low & 0 & 0.091 & 0 & 0.301 & 0 & 0 & 0 & 0 & 0 & 0 & 0 \\
\hline & High & 0 & 0.13 & 0 & 0.352 & 0 & 0 & 0 & 0 & 0 & 0 & 0 \\
\hline \multirow[t]{2}{*}{${ }^{\mathrm{b}}$ Dinoflagellate } & Low & 0 & 0 & 0 & 0 & 0 & 0 & 0 & 0 & 0 & 0 & 0.375 \\
\hline & High & 0 & 0 & 0 & 0 & 0 & 0 & 0 & 0 & 0 & 0 & 0.285 \\
\hline \multirow[t]{2}{*}{${ }^{\mathrm{c}} c_{3}$-flagellates } & Low & 0.133 & 0.072 & 0.046 & 0.171 & 0.11 & 0 & 0 & 0 & 0 & 0 & 0 \\
\hline & High & 0.145 & 0.08 & 0.039 & 0.125 & 0.056 & 0 & 0 & 0 & 0 & 0 & 0 \\
\hline \multirow[t]{2}{*}{${ }^{\mathrm{c}}$ Cryptophytes } & Low & 0 & 0.079 & 0 & 0 & 0 & 0 & 0 & 0 & 0.162 & 0 & 0 \\
\hline & High & 0 & 0.075 & 0 & 0 & 0 & 0 & 0 & 0 & 0.201 & 0 & 0 \\
\hline \multirow[t]{2}{*}{${ }^{\mathrm{b}}$ Chryso-Pelago } & Low & 0.038 & 0.105 & 0.386 & 0.141 & 0 & 0 & 0 & 0 & 0 & 0 & 0 \\
\hline & High & 0.044 & 0.111 & 0.324 & 0.131 & 0 & 0 & 0 & 0 & 0 & 0 & 0 \\
\hline \multirow[t]{2}{*}{${ }^{\mathrm{c}}$ Hapto-7 } & Low & 0.079 & 0.071 & 0.008 & 0.154 & 0.321 & 0 & 0 & 0 & 0 & 0 & 0 \\
\hline & High & 0.036 & 0.061 & 0.006 & 0.122 & 0.303 & 0 & 0 & 0 & 0 & 0 & 0 \\
\hline \multirow[t]{2}{*}{${ }^{\mathrm{c}}$ Prasino-2 } & Low & 0 & 0 & 0 & 0 & 0 & 0.03 & 0 & 0.424 & 0 & 0.02 & 0 \\
\hline & High & 0 & 0 & 0 & 0 & 0 & 0.017 & 0 & 0.418 & 0 & 0.049 & 0 \\
\hline \multirow[t]{2}{*}{${ }^{\mathrm{c}}$ Prasino-3 } & Low & 0 & 0 & 0 & 0 & 0 & 0.054 & 0.209 & 0.271 & 0 & 0.004 & 0 \\
\hline & High & 0 & 0 & 0 & 0 & 0 & 0.043 & 0.136 & 0.222 & 0 & 0.005 & 0 \\
\hline \multirow[t]{2}{*}{${ }^{\mathrm{c}}$ Chlorophytes } & Low & 0 & 0 & 0 & 0 & 0 & 0.035 & 0 & 0.037 & 0 & 0.143 & 0 \\
\hline & High & 0 & 0 & 0 & 0 & 0 & 0.023 & 0 & 0.217 & 0 & 0.12 & 0 \\
\hline
\end{tabular}

independent CHEMTAX runs for shelf and basin samples to minimize the effects of the growth and nutrient conditions on the pigment interpretation.

The ratio of pigment / Chl $a$ for various algal taxa used as "seed" values for the CHEMTAX analysis were chosen from the literature. However, the pigment ratios for a real sample are unlikely to be known exactly due to regional variations of individual species, strain differences within a given species and local changes in algal physiology due to envi- ronmental factors such as temperature, salinity, light field, nutrient stress and mixing regimes (Mackey et al., 1996). Therefore, to test the sensitivity of CHEMTAX, 10 further high light and low light pigment ratio tables were generated by multiplying each cell of our initial ratio matrix by a randomly determined factor $F$, where $F=1+S \cdot(R-0.5) . S$ is a scaling factor (normally 0.7 ), and $R$ is a random number between 0 and 1 generated using the Microsoft Excel RAND function. The random ratio matrices were created 
using a template provided by Thomas Wright (CSIRO, Australia). For the shelf and basin subset, each of the 10 low light and high light ratio tables were used as the starting point for a CHEMTAX optimization using iteration and a steepest descent algorithm to find a minimum residual. The solution with the smallest residual (final ratio matrix, Table 3b) was used to estimate the abundance of the phytoplankton classes, i.e., the part of the total $\mathrm{Chl} a$ associated with each phytoplankton class. The results of the 10 matrices were used to calculate the average and standard deviation (SD) of the abundance estimates.

\section{Results and discussion}

\subsection{Spatial distribution of accessory pigments}

The distribution of TChl $a$ showed large horizontal and vertical variability in the Beaufort Sea in August 2009. A subsurface chlorophyll $a$ maximum (SCM) was generally present both over the shelf $(35 \pm 8 \mathrm{~m})$ and deep waters of the Beaufort Sea $(61 \pm 7 \mathrm{~m})$. Surface TChl $a$ was twice as high on the shelf $\left(0.20 \pm 0.13 \mathrm{mgChl} a \mathrm{~m}^{-3}\right.$, Fig. 2a) than in the basins (Fig. 2c) and SCM TChl $a$ was 10 times higher over the shelf $\left(2.84 \pm 2.55 \mathrm{mgChl} a \mathrm{~m}^{-3}\right.$, Fig. $\left.2 \mathrm{~b}\right)$ than in the basins (Fig. 2d). The highest chlorophyll biomasses (> $6 \mathrm{mg} \mathrm{Chl} a \mathrm{~m}^{-3}$ ) were observed at the SCM close to the shelf break (St 260 and 780, Figs. 1 and 2b). Such high values contrast with the low ones $\left(<1 \mathrm{mg} \mathrm{Chl} a \mathrm{~m}^{-3}\right)$ observed during autumn in the same area in 2002 and 2003 (Brugel et al., 2009).

The concentrations of accessory pigments also varied significantly across shelf and basin stations and between the surface and the SCM. The highest biomasses, observed at the SCM of shelf waters, were associated with the dominance of fucoxanthin (Fuco) and chlorophyll $c_{1}+c_{2}\left(\mathrm{Chl} c_{1}+c_{2}\right)$. These two pigments, characteristic of diatoms, represented 56 and $23 \%$ of the total accessory pigments biomass, respectively (Fig. 2b). The presence of degradation pigments of Chl $a$ at the SCM of the shelf (Chlide $a+$ pheophorbide $a$ (Pheide $a$ ) + pheophytin $a$ (Phe $a$ ) $=14 \%$ of total accessory pigments) indicated the presence of zooplankton fecal pellets or cellular senescence (Bidigare et al., 1986). The remaining $7 \%$ were mainly associated with photoprotective carotenoids (Diadino + Diato + Zea + Viola + Car $=6.7 \%$ of total accessory pigments).

In surface waters of the shelf (Fig. 2a), pigment assemblages were indicative of diverse communities consisting of diatoms, dinoflagellates, cryptophytes, prymnesiophytes and green algae. The contribution of Fuco (34\% of total accessory pigments), $\mathrm{Chl} c_{1+} c_{2}$ (13\% of total accessory pigments) and degradation products of $\mathrm{Chl} a(9.7 \%)$ decreased while the proportion of $\mathrm{Chl} b$ to total accessory pigments increased from $0.3 \%$ at the SCM to $9 \%$ at the surface. Peri and Allo pigments, reflecting dinoflagellates and cryptophytes, were observed at stations 394 and 680 but remained poorly rep- resented elsewhere. The high contribution of photoprotective carotenoids to total accessory pigments $(16.1 \%)$, compared to surface waters $(6.7 \%)$, indicated the response of phytoplankton to high light (Frank et al., 1994; Fujiki and Taguchi, 2002).

In the basin, pigments associated with green algae $(\mathrm{Chl} b$, Pras, neoxanthin (Neo), Viola, Lut) and nanoflagellates (Hex-fuco, But-fuco, $\mathrm{Chl} c_{3}$ ) increased while diatom pigments decreased, i.e., Fuco and $\mathrm{Chl} c_{1+} c_{2}$ (Fig. 2c and d). The highest contribution of nanoflagellate pigments Hexfuco $(18 \%)$, But-fuco $(9 \%)$ and $\mathrm{Chl} c_{3}(9 \%)$ were observed at the SCM. In contrast, the contribution of the green algal pigments, Chl $b$ (23\%), Viola (5.9\%) and Lut (4.3\%), was higher at the surface than at the SCM. Degradation products represented less than $3 \%$ of the total pigment load. Like on the shelf, the contribution of photoprotective carotenoids was 3 to 4 times higher at the surface $(\approx 20 \%)$ than at the SCM $(5.5 \%)$.

The few historical pigment data available for the Canadian Arctic show spatial patterns similar to those reported here. Hill et al. (2005) in the western Beaufort Sea and Coupel et al. (2012) in the Canada Basin and the Chukchi Sea agree on the dominance of Fuco and $\mathrm{Chl} c_{1+} c_{2}$ over the shelf and an increase of pigments indicative of green algae (Pras, $\mathrm{Chl} b$ ) and nanoflagellates (Hex-fuco, But-fuco) offshore. However, some differences also exist, possibly reflecting the influence of distinct environmental conditions on the phytoplankton assemblage. While in summer 2008 a high contribution of Fuco was found in the surface waters of the southern Canada basin free of ice (Coupel et al., 2012), Hill et al. (2005) in summer of 2002, in the same area but covered by ice, found lower Fuco and a greater contribution of Pras. Furthermore, the contribution of Pras at the SCM of basin stations was twice as high in 2008 compared to 2002. Finally the pigments Hex-fuco and $\mathrm{Chl} c_{3}$, characteristic of prymnesiophytes, contributed less in both 2002 and 2008 studies than in our 2009 data.

\subsection{Phytoplankton group contribution}

The surface and subsurface pigment assemblages shown in Fig. 2 were converted into relative contributions of main phytoplankton groups to TChl $a$ with the CHEMTAX software. We first tested the sensitivity of the software by running CHEMTAX on our data set using five different ratio matrices from previous studies of polar oceans. The resulting CHEMTAX interpretation of the pigment assemblages varies widely according to the matrix used (Fig. 3). The diatom contribution to SCM assemblages at basin stations of the Beaufort Sea varied from $3.5 \%$ when using a parameterization for the North Water Polynya to $40 \%$ when using a parameterization for the Antarctic Peninsula. Similarly, the prasinophytes contribution ranged from 15 to $46 \%$ depending on the initial ratio matrix used. These differences arise from the different species and pigment / TChl $a$ ratios used as seed values 

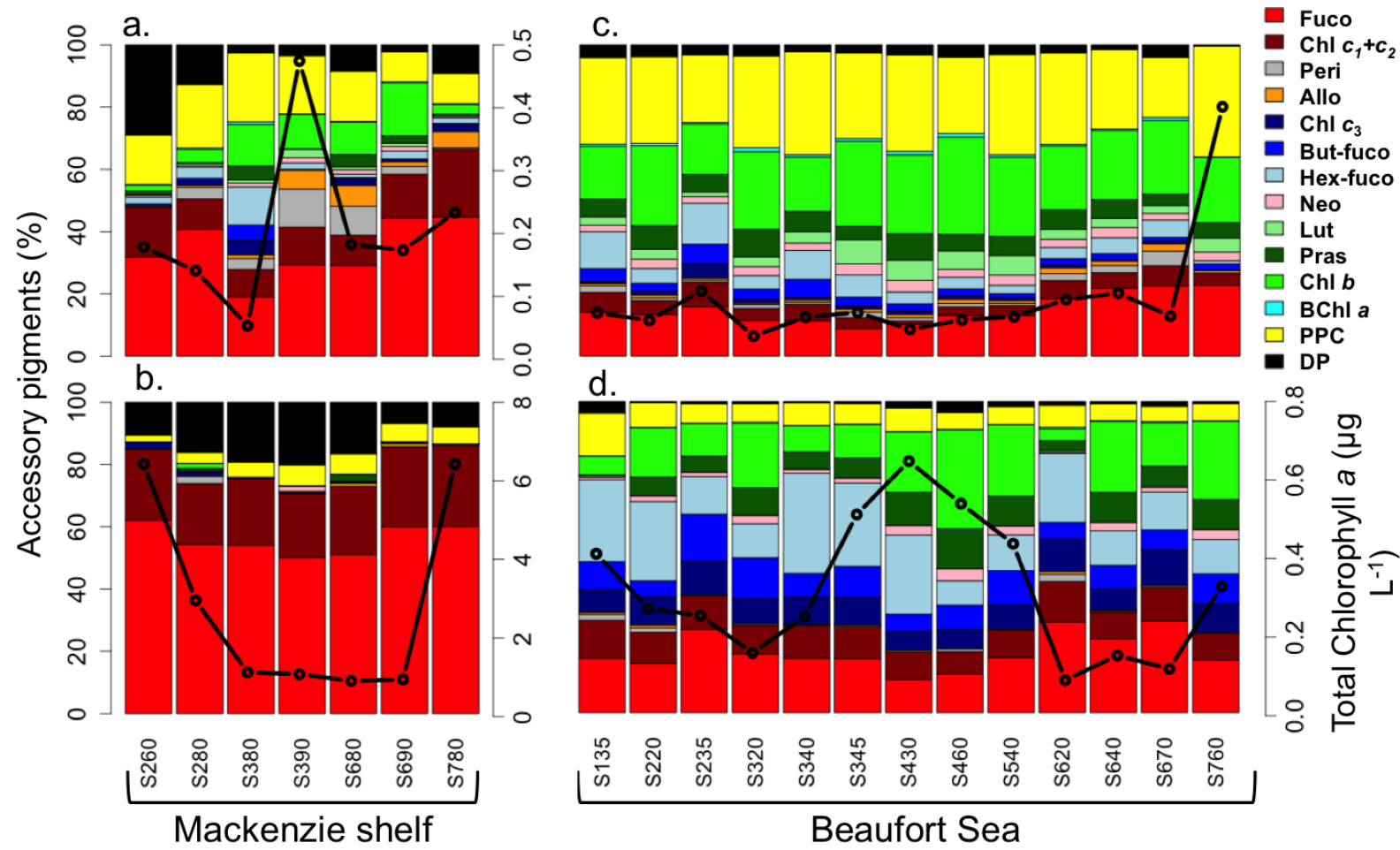

Figure 2. Relative contribution of accessory pigments to total accessory pigment (wt: wt) in (a, c) surface water and at the (b, d) subsurface chlorophyll maximum (SCM) depth of the (a, b) Mackenzie shelf and (c, d) deep waters of the Beaufort Sea. The black line with circle represents the chlorophyll $a$ concentration. DP: degradation pigments (Chlide $a+$ Pheide $a+$ Phe $a$ ); PPC: photoprotective carotenoids (i.e., Diadino + Diato + Zea + Viola + Car). Pigment abbreviations are defined in Table 1. Please note the different TChl $a$ scales between the four panels. The same TChl $a$ scale $\left(0-0.8 \mu \mathrm{gL}^{-1}\right)$ was used for the panels (c) and (d).

in CHEMTAX. Optimizing seed values for our study clearly requires an investigation of dominant species and their pigment content in the Beaufort Sea. Here we did this by first identifying the dominant phytoplankton species under optical microscopy (see Sect. 2.4). We tested the sensitivity of CHEMTAX by multiplying each number of the ratio matrix by a random factor. Our results show that by independently and randomly varying the ratios, up to $35 \%$ of their initial values do not significantly modify the abundance estimates of the phytoplankton classes by CHEMTAX. The standard deviation in estimating the relative abundance of the phytoplankton classes ranged between 0.1 and $8 \%$ with an average deviation of $2 \%$. Highest deviation was found for the Prasino-2 and Prasino-3 classes (about 5\%) while the variation of the others groups were less than $2 \%$ on average. We suggest that changing the starting ratios by more or less a threshold value of $50 \%$ ensures confidence in the CHEMTAX output.

After running CHEMTAX on our data set, the stations were classified with the $k$-means clustering method (MacQueen, 1967) according to their pigment resemblance/dissemblance. Four significantly different phytoplankton communities were highlighted by the cluster classification (Fig. 4a). Cluster 1 was dominated at $95 \%$ by di- atoms and represented the SCM of stations located on the shelf as well as surface waters close to Cape Bathurst and the Mackenzie Estuary (Fig. 4b and c). Cluster 2 included surface waters of basin and shelf stations, characterized by a dominance of green algae (40\%) shared between type 3 prasinophytes $(25 \%)$ and chlorophytes (16\%). Diatoms, dinoflagellates and cryptophytes were also major contributors of cluster 2 with 20,12 and $7 \%$, respectively. Clusters 3 and 4 were restricted to the SCM of basin stations and characterized by a high contribution of flagellates (Fig. 4a and c). Cluster 4 was dominated by prymnesiophytes $(41 \%)$ while $c_{3}$-flagellates dominated cluster $3(28 \%)$. The contribution of green algae remained high in clusters 3 and 4 but was shared between prasinophytes of types 2 and 3 while chlorophytes were no longer present.

\subsection{Linkages between phytoplankton assemblages and environmental factors}

The four assemblages of phytoplankton inferred from pigments (Fig. 4a) were compared to environmental conditions (Table 4). Statistical analysis (Student's $t$ test, Table S1 in the Supplement) showed significant difference between the environmental conditions of the four clusters. The green algae, especially pico-sized prasinophytes of type 3 , dominated 
Table 4. Physical, chemical and biological characteristics (mean + SD) for each cluster presented in Fig. 4. Cluster 1 is subdivided for samples collected in surface water (surf) and subsurface chlorophyll maximum (SCM) depth. PAR: $\mu \mathrm{Mm}^{-2} \mathrm{~s}^{-1}$ of the surface photosynthetically active radiation; C / TChl $a$ : ratio of algal carbon biomass to total chlorophyll $a$ concentration (i.e., TChl $a=\mathrm{Chl} a+\mathrm{Chlid} a$ ).

\begin{tabular}{|c|c|c|c|c|c|c|c|c|c|}
\hline & & & Salinity & & $\mathrm{NO}_{3}^{-}$ & $\mathrm{NH}_{4}^{+}$ & $\mathrm{PO}_{4}^{3-}$ & \multirow{2}{*}{$\begin{array}{r}\text { TChl } a \\
\left(\mu g \mathrm{~L}^{-1}\right)\end{array}$} & \multirow[t]{2}{*}{$\mathrm{C} / \mathrm{TChl} a$} \\
\hline & (m) & $\left({ }^{\circ}\right)$ & PSU & $\left(\mu \mathrm{Mm}^{-2} \mathrm{~s}^{-1}\right)$ & \multicolumn{3}{|c|}{$\left(\mu \mathrm{mol} \mathrm{L}^{-1}\right)$} & & \\
\hline Clust & \pm & $0.8 \pm$ & 2 & 35 & 3.1 & 0.09 & 0.96 & 1.80 & 150 \\
\hline Cluster 1 surf $(n=4)$ & $5 \pm 3$ & $4.2 \pm 1$ & $26.7 \pm 3.7$ & $100 \pm$ & $0.2 \pm 0.2$ & $0.01 \pm 0.01$ & $0.50 \pm$ & $0.16 \pm$ & $280 \pm 150$ \\
\hline Cluster $1 \mathrm{SCM}(n=7)$ & $35 \pm 8$ & $-1.0 \pm 0.1$ & $31.7 \pm 0.4$ & $2.2 \pm 2.3$ & $5.1 \pm 1.6$ & $0.15 \pm 0.12$ & $1.27 \pm 0.11$ & $2.73 \pm 2.55$ & $49 \pm 23$ \\
\hline Cluster $2(n=15)$ & $2 \pm 1$ & $3.7 \pm 2.9$ & $24.1 \pm 6.4$ & $129 \pm 85$ & $0.1 \pm 0.1$ & $0.02 \pm 0.04$ & $0.54 \pm 0.10$ & $0.12 \pm 0.13$ & $160 \pm 110$ \\
\hline Cluster $3(n=8)$ & $66 \pm 4$ & $-1.1 \pm 0.1$ & $31.5 \pm 0.2$ & $2.2 \pm 1.2$ & $5.1 \pm 2.7$ & $0.02 \pm 0.02$ & $1.26 \pm 0.20$ & $0.28 \pm 0.16$ & $38 \pm 23$ \\
\hline Cluster $4(n=6)$ & $56 \pm 5$ & $-1.1 \pm 0.1$ & $31.0 \pm 0.4$ & $4.7 \pm 1.7$ & $0.5 \pm 0.2$ & $0.03 \pm 0.02$ & $0.86 \pm 0.06$ & $0.36 \pm 0.20$ & $34 \pm 25$ \\
\hline
\end{tabular}

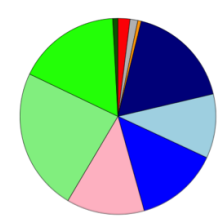

North Water Polynya (Vidussi et al., 2004)

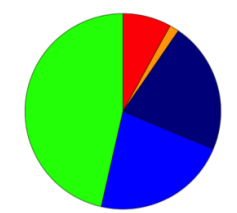

Antarctic Peninsula (Rodriguez et al., 2002)

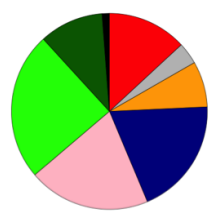

Bering Sea (Suzuki et al., 2002)

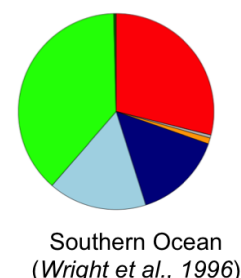

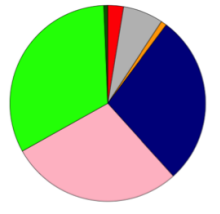

Barents Sea (Not et al., 2005)

Diatoms

$\square$ Dinoflagellates

$\square$ Cryptophytes

- Hapto-7

$\square$ Hapto-8

- $c_{3}$-flagellates

$\square$ Chryso-Pelago

$\square$ Prasino-2

- Prasino-3

$\square$ Chlorophytes

- Cyano-4

Figure 3. Average contribution of major algal groups to total chlorophyll $a$ (Chl $a$ ) concentration at the subsurface chlorophyll maximum (SCM) depth in the deep waters of the Beaufort Sea calculated with the CHEMTAX software using five different pigment / Chl $a$ ratio matrices. Ratio matrices are from previous studies conducted in polar oceans: Vidussi et al. (2004) in the North Water Polynya, Suzuki et al. (2002) in the Bering Sea, Not et al. (2005) in the Barents Sea, Rodriguez et al. (2002) around the Antarctic Peninsula and Wright et al. (1996) in the Southern Ocean. According to Higgins et al. (2011): Hapto-7: haptophytes type 7; Hapto8: haptophytes type 8; Chryso-Pelago: chrysophytes and pelagophytes; Prasino-2: prasinophytes type 2; Prasino-3: prasinophytes type 3; Cyano-4: cyanobacteria type 4 .

the oligotrophic $\left(0.12 \pm 0.13 \mathrm{mgChl} a \mathrm{~m}^{-3}\right)$ and nutrientdepleted surface waters (cluster 2). This is consistent with the high surface / volume ratios of the picophytoplankton, which allows for more effective nutrient acquisition and better resistance to sinking. The dominance of the prasinophyte $\mathrm{Mi}$ cromonas sp. in the Beaufort Sea has been previously highlighted and was shown to be more pronounced under reduced sea-ice cover (Comeau et al., 2011; Li et al., 2009; Lovejoy et al., 2007).

Otherwise, the high Lut/Chl $b$ ratio $(\approx 0.2)$ points out a significant contribution of chlorophytes in surface waters, a group including several freshwater species. The restriction
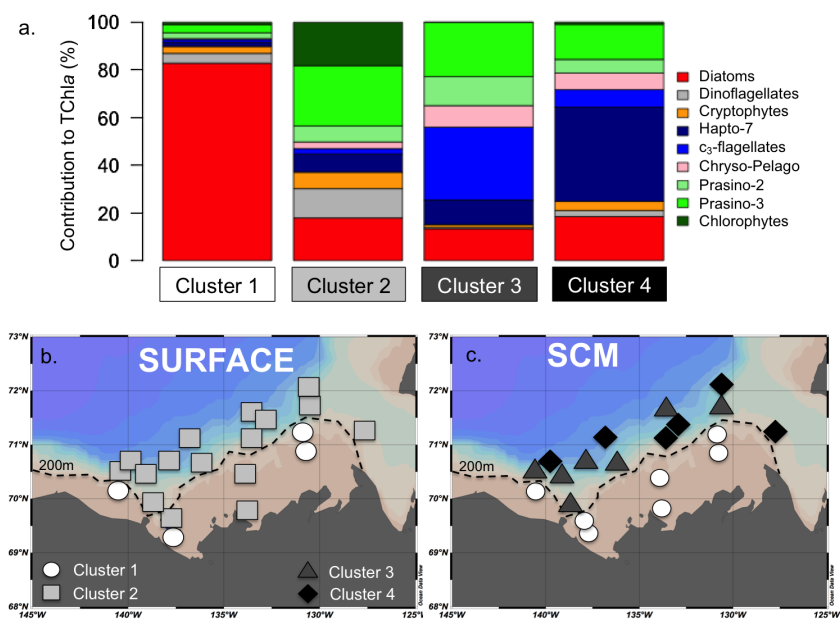

Figure 4. (a) Relative contribution of major algal groups to total chlorophyll $a$ (Chl $a$ ) concentration (calculated by CHEMTAX) for four groups of samples with similar pigment composition (clusters) determined with the $k$-means clustering method (MacQueen, 1967). The geographical position of the four groups of samples (four clusters) is mapped for the (b) surface water and (c) subsurface chlorophyll maximum (SCM) depth. According to Higgins et al. (2011): Hapto-7: haptophytes type 7; Chryso-Pelago: chrysophytes and pelagophytes; Prasino-2: prasinophytes type 2; Prasino3: prasinophytes type 3 .

of this group to the surface low-salinity waters in our study leads us to believe the Mackenzie River could have spread them in the Beaufort Sea as previously proposed by Brugel et al. (2009). Finally, dinoflagellates identified in surface waters of cluster 2 have been previously underlined as a major contributor of the large autotrophic cells abundance on the Mackenzie shelf (Brugel et al., 2009).

The cluster 1 was subdivided in two subclusters (cluster 1 surf and cluster 1 SCM, Table 4) because of the important environmental difference between surface and SCM. At the SCM of shelf stations (cluster 1), nitrate concentrations were high $\left(3.1 \pm 2.8 \mu \mathrm{mol} \mathrm{L}{ }^{-1}\right.$, Table 4$)$ and possibly support substantial new production. The highest biomasses of the cruise $\left(1.8 \pm 2.3 \mathrm{mgChl} a \mathrm{~m}^{-3}\right.$ and $\left.80 \pm 45 \mathrm{mgC} \mathrm{m}^{-3}\right)$ were measured in these waters and were related to a high dominance 
of diatoms. The diatom population could be fed by a crossshelf flow of nitrate-rich waters from the basin to the shelf bottom (Carmack et al., 2004; Forest et al., 2014). The optical microscopy showed a strong dominance of the colonial centric diatoms Chaetoceros socialis $\left(\approx 1 \times 10^{6}\right.$ cell $\mathrm{L}^{-1}$, data not shown). This species is relatively small $(\approx 10 \mu \mathrm{m})$ and often observed succeeding the larger ones, such as Thalassiosira spp. or Fragilariopsis spp., as the ice-free season advances (Booth et al., 2002; Vidussi et al., 2004; von Quillfeldt, 2000). Diatoms also dominated surface waters north of Cape Bathurst and near the Mackenzie Estuary but their biomass was lower and related to different species according to microscopy (i.e., Thalassiosira nordenskioeldii and Pseudo-nitzschia sp.). Dominance of diatoms in cluster 1 surf showed by both microscopy and pigment strongly differ from the surface communities associated with the cluster 2 and characterized by green algae, dinoflagellates and haptophytes. However, environmental conditions associated with these two clusters (Table 4) were similar and cannot explain the differences in communities. We suppose that the higher dominance of diatoms in surface waters of the cluster 1 could be a remnant of a past event such as an upwelling. Sporadic high concentration of Chl $a$ and occurrence of Chaetoceros socialis was previously observed in September 2005 at the SCM and at the surface following local upwelling events and advective input of nutrients from the deep basin (Comeau et al., 2011).

The SCM of basin stations was dominated by two distinct flagellate assemblages, which are distinguished by their Hex-fuco / But-fuco ratio. The prymnesiophytes characterized by a high Hex-fuco / But-fuco ratio $(\approx 3)$ dominated cluster 4 while $c_{3}$-flagellates associated with a low Hexfuco / But-fuco ratio $(\approx 1)$ dominated cluster 3 . The shift in assemblages was related to the vertical position of the SCM relative to the nitracline. The prymnesiophytes, mainly associated with Chrysochromulina sp., dominated when the SCM matched the nitracline, whereas $c_{3}$-flagellates dominated when the SCM was below the nitracline (Fig. 5). Incidentally, the relatively shallow prymnesiophyte-dominated $\mathrm{SCM}(\approx 56 \mathrm{~m})$ was exposed to more light $(\mathrm{PAR}=4.7 \pm$ $1.7 \mu \mathrm{M} \mathrm{m}^{-2} \mathrm{~s}^{-1}$, Table 4$)$ but less nitrate $\left(0.5 \pm 0.2 \mu \mathrm{molL}^{-1}\right.$, Table 4) than the deeper $c_{3}$-flagellate-dominated SCM $(\approx$ $66 \mathrm{~m})$ that occurred at a PAR of $2.2 \pm 1.2 \mu \mathrm{Mm}^{-2} \mathrm{~s}^{-1}$ and 10 -fold higher nitrate concentrations $\left(5.1 \pm 2.7 \mu \mathrm{molL}^{-1}\right)$. We stated that the $c_{3}$-flagellate group was comprised primarily of raphidophytes. Indeed, microscopy showed that raphidophytes were present only at the SCM of basin stations, where they represented $25 \%$ of phytoplankton carbon biomass (Table 2). The lack of photoprotective pigments in raphidophytes could explain why this group is restricted to deep SCM (Van den Hoek et al., 1995). A recent study based on molecular approaches showed an increase of prymnesiophyte-type Chrysochromulina sp. since 2007 in the Beaufort Sea (Comeau et al., 2011). The prevalence of flagellates was attributed to the gradual freshening

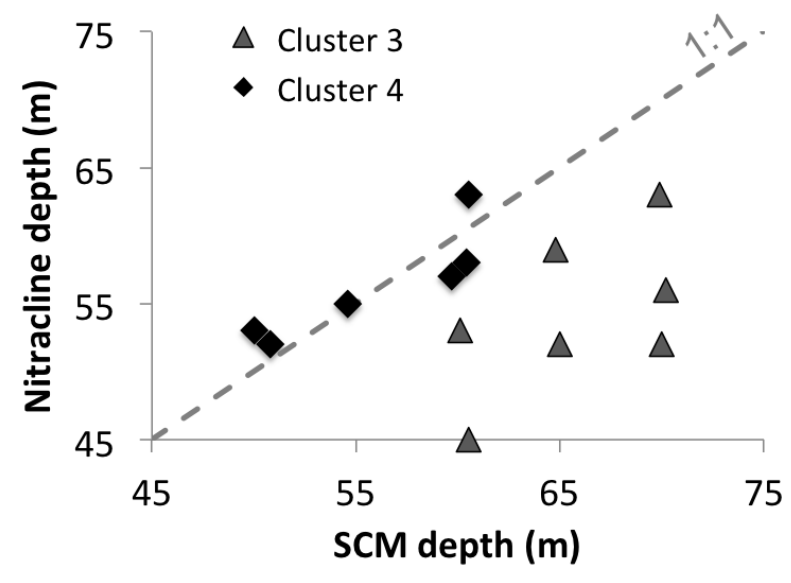

Figure 5. Relationship between the nitracline depth and the subsurface chlorophyll $a$ maximum (SCM) depth for samples of clusters 3 (grey triangle) and 4 (black diamond). The dashed line represents a $1: 1$ relationship. Note the SCM depth matches with the nitracline depth for cluster 4 samples. In contrast, the SCM is deeper than the nitracline depth for cluster 3 samples.

of the Beaufort Sea and increasing stratification. The lack of mixing may act to force the SCM deeper, resulting in lower ambient PAR (McLaughlin and Carmack, 2010). The dominance of nanoflagellates has been previously noticed in SCM waters of the Canada Basin in conditions of intense freshwater accumulation (Coupel et al., 2012).

\subsection{Cell abundance and carbon biomass: implications for carbon export}

The chemotaxonomic interpretation of pigments remains semi-quantitative. CHEMTAX provides the percentage contribution of phytoplankton groups according to their relative contribution to TChl $a$. This information is relevant to monitor changes in the phytoplankton communities changes in the plankton pigment composition caused by modifications in the environment such as nutrients or light regimes. A change in the relative contribution of pigments is a clear indication of change in the structure or in the acclimation of phytoplankton communities. Nevertheless, to investigate the implications of phytoplankton changes on food webs and the biological pump, the pigment data must be converted into contribution to total abundance or into carbon biomass. However, this conversion is not always straightforward since pigment chemotaxonomy and microscopy measure different parameters with different units (i.e., cell numbers, $\mathrm{mg} \mathrm{Cm}^{-3}$ vs. $\mathrm{mg} \mathrm{Chl} a \mathrm{~m}^{-3}$ ).

Not surprisingly, the contribution of different phytoplankton groups to total cell abundance differed from their contribution to total phytoplankton carbon biomass. The picophytoplankton largely dominated cell abundance, except on the shelf where diatoms dominated the SCM (Fig. 6, Table 2), but contributed only $0-3$ and $6-7 \%$ of the total 

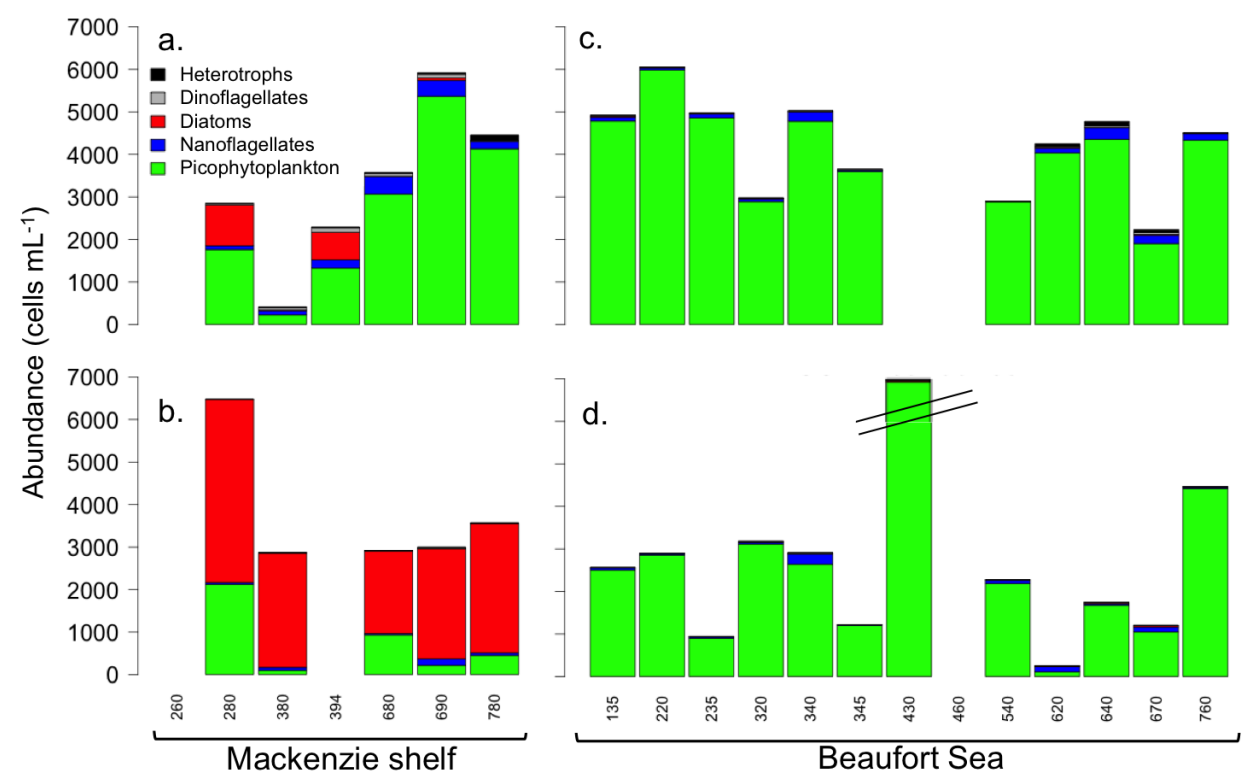

Figure 6. Abundance of five protist groups in (a, c) surface and at the (b, d) subsurface chlorophyll maximum (SCM) depth of the (a, b) Mackenzie shelf and (c, d) deep waters of the Beaufort Sea.
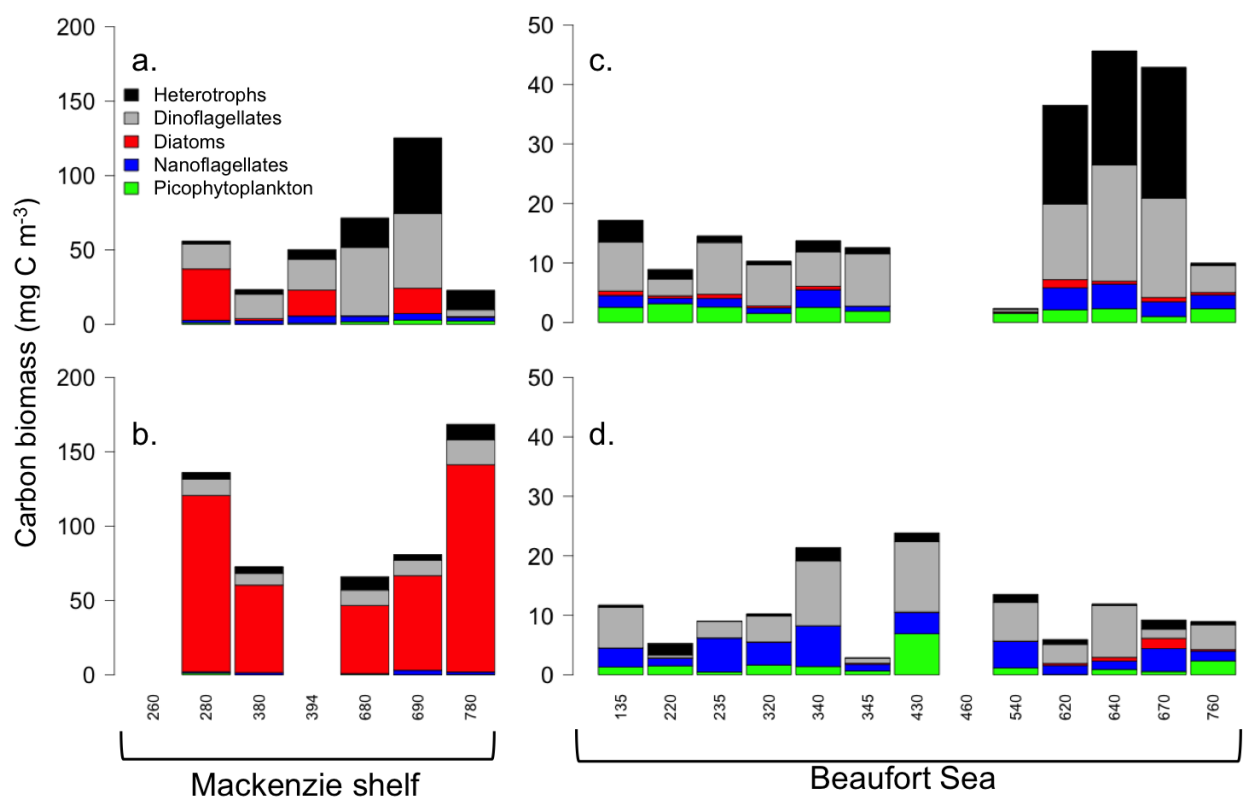

Figure 7. Carbon biomass of five protist groups in (a, c) surface and at the (b, d) subsurface chlorophyll maximum (SCM) depth of the (a, b) Mackenzie shelf and (c, d) deep waters of the Beaufort Sea.

phytoplankton carbon biomass over the shelf and basin, respectively. Phytoplankton larger than $3 \mu \mathrm{m}$ dominated carbon biomass at all stations (Fig. 7, Table 2). The minimum total phytoplankton abundance was observed at SCM of the basin $\left(2500 \pm 2500\right.$ cell $\left.\mathrm{mL}^{-1}\right)$ and the maximum in surface of the shelf $\left(4400 \pm 1400\right.$ cell $\left.\mathrm{mL}^{-1}\right)$. Nevertheless, the total phytoplankton abundance over the shelf was not significantly higher than in the Beaufort basin. Conversely, average carbon biomass at the surface was 3 times higher on the shelf $\left(64 \pm 22 \mathrm{mg} \mathrm{C} \mathrm{m}^{-3}\right)$ than in the basin $\left(25 \pm 7 \mathrm{mg} \mathrm{Cm}^{-3}\right)$. The difference was more pronounced at the SCM, where carbon biomass was 8 times higher at shelf stations $(110 \pm$ $\left.57 \mathrm{mg} \mathrm{Cm}^{-3}\right)$ than at basin stations $\left(14 \pm 5 \mathrm{mg} \mathrm{Cm}^{-3}\right)$. This contrast was attributed to the dominance of SCM carbon biomass (up to $90 \%$ ) by diatoms on the shelf. Otherwise the carbon biomass was dominated at $50-75 \%$ by dinoflagellates, which represented less than $15 \%$ of total cell abundance (Table 2). The highest biomasses of dinoflagellates 
occurred in surface waters of the Mackenzie canyon area (stations 620, 640, 670, 680, 690; Fig. 6a, 6c) and were associated with high biomasses of other heterotrophs, mainly ciliates. Raphidophytes also made a substantial contribution (26\%) to the total phytoplankton carbon biomass at the SCM of basin stations.

Since the estimated contributions of phytoplankton groups to carbon biomass differ from contributions to cell abundance one might ask which of the two variables should be reflected by the chemotaxonomic approach. Overall, the contribution of algal groups to TChl $a$ (CHEMTAX) showed better agreement with their contribution to total cell abundance (Fig. 8) than to total carbon biomass (Fig. 9). The best agreement between CHEMTAX and relative abundance and biomass was obtained for diatoms (Figs. 8a and 9a). For nanoflagellates and picophytoplankton, CHEMTAX showed a moderate correlation with relative abundance (Fig. $8 b$ and c) and a weak one with relative biomass (Fig. $9 b$ and c). In fact, CHEMTAX underestimates the importance of picophytoplankton and nanoflagellates in terms of cell abundance but overestimates their importance in terms of carbon biomass, as shown by the position of data points with respect to the $1: 1$ line in Figs. 8b, c and 9b, c. We observed that the contribution of picophytoplankton to TChl $a$ became significant only when its contribution to total cell abundance exceeded $80 \%$ (Fig. 8b). Obviously, the underestimation of small phytoplankton abundance by chemotaxonomy is explained by the lower amount of pigment including Chl $a$ in small cells compared to large cells. On the other hand, the ratio of carbon to TChl $a(\mathrm{C} / \mathrm{TChl} a)$ in phytoplankton increases with cell volume (Geider et al., 1986). The fact that small cells are richer in Chl $a$ than large cells for a similar carbon biomass could explain the overestimation in the contribution of small phytoplankton to total carbon biomass by the chemotaxonomy. Based on the relationships between cell volume and content in Chl $a$ and carbon proposed by Montagnes et al. (1994), we calculate the ratio C / TChl $a$ of a Micromonas sp. $\left(1 \mathrm{\mu m}^{3}\right)$ to be twice as low than in diatoms or dinoflagellates $\left(1000 \mu^{3}\right)$. Indeed, the pigments are mainly in the periphery of the cell, which means that the intracellular pigment density increases as ratio of surface area to volume increases. This is clearly demonstrated by comparing the mean $\mathrm{C} / \mathrm{TChl} a$ ratio of the surface waters dominated by diatoms (cluster 1 surf: C / TChl $a=280 \pm 150$, Table 4), with the surface waters dominated by Micromonas sp. (cluster 2, C / TChl $a=160 \pm 110$ ). The weaker relationship between CHEMTAX and carbon biomass could have been induced by these variations in the C/TChl $a$ ratios of the phytoplankton and by the different transfer equations used to determine the carbon biomass from the biovolume (see Sect. 2.3).

No significant correlation was observed between CHEMTAX and microscopy for dinoflagellates, prymnesiophytes, chrysophytes, chlorophytes and cryptophytes. Such inconsistences are mainly attributed to the low accuracy of vi-

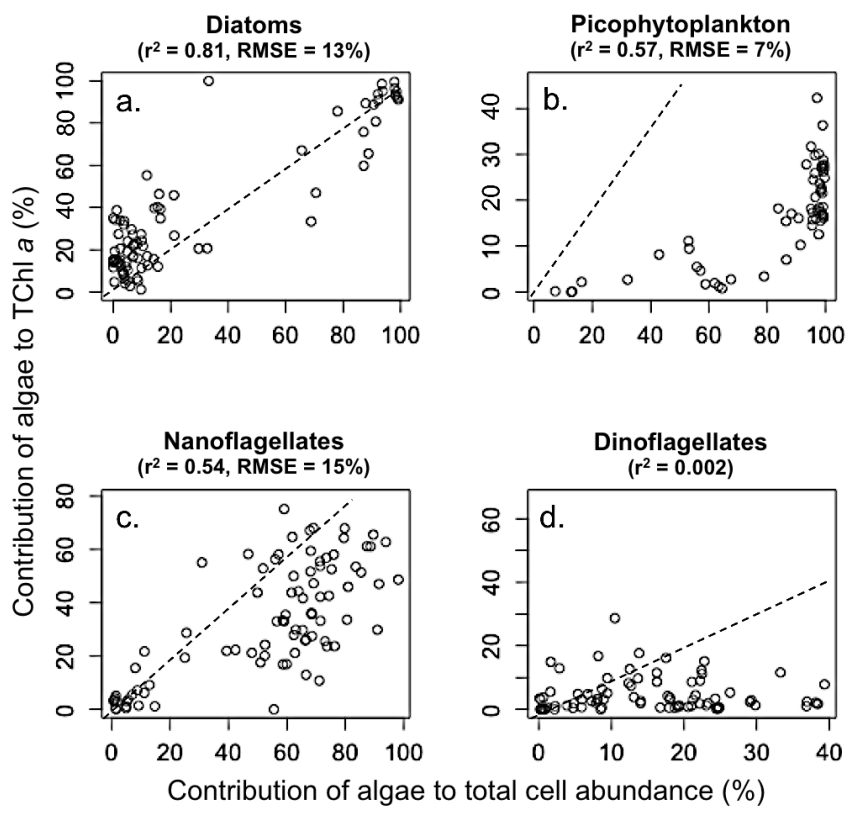

Figure 8. Scatter diagrams of the contribution of (a) diatoms, (b) picophytoplankton, (c) nanoflagellates and (d) dinoflagellates to total chlorophyll $a(\mathrm{Chl} a)$ concentration (calculated by CHEMTAX) as a function of their contribution to total cell abundance. The dashed line represents a $1: 1$ relationship. The Pearson correlation coefficient $\left(r^{2}\right)$ is indicated for each algal group. The root-mean-square error (RMSE) depicts the predictive capabilities of cell abundance from the CHEMTAX-derived algal groups. In total, $95 \%$ of the algal cell abundance estimated from the CHEMTAX-derived algal groups is in the range $\pm 2 \times$ RMSE from the least-squares regression line.

sual counts for nano-sized flagellates. Up to $35 \%$ of the visible flagellates were categorized as unidentified and others may have been overlooked because of poor conservation. The most surprising divergence between CHEMTAX and microscopy occurred for dinoflagellates (Figs. 8d and 9d). Despite the high contribution of this group to carbon biomass (Fig. 7), it rarely constituted more than $10 \%$ of the TChl $a$ according to CHEMTAX. While such a discrepancy may generally arise from the large biovolume and high C / TChl $a$ ratio of dinoflagellates compared to other groups, in our study it was presumably caused by the inability of CHEMTAX to detect dinoflagellates of the genera Gymnodinium and Gyrodinium, which lack Peri (Jeffrey et al., 1997). Indeed, we found no correlation between dinoflagellate abundance and the unambiguous pigment Peri used by CHEMTAX to detect this group ( $r^{2}=0.04$, not shown). Only the surface waters of the stations 394 and 680 dominated by an autotrophic dinoflagellate (Heterocapsa rotundata) known to possess a relative high Peri content showed the presence of Peri in relative high proportions. Molecular analyses indicated that the nonphotosynthetic heterotrophic species $G y$ rodinium rubrum dominated the dinoflagellate assemblages in the region (D. Onda, personal communication, 2014). 

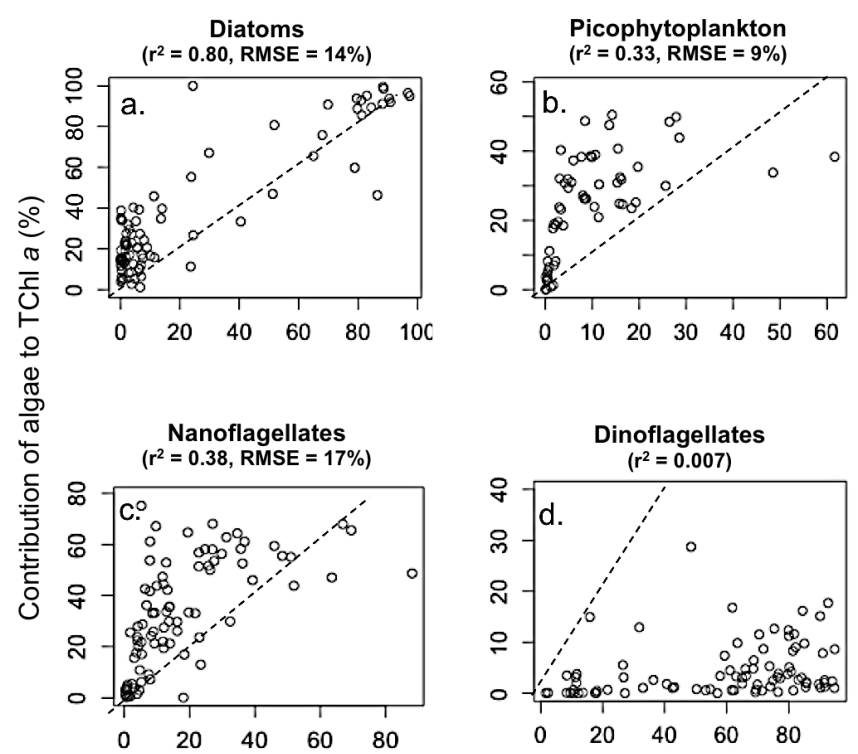

Contribution of algae to total carbon biomass (\%)

Figure 9. Scatter diagrams of the contribution of (a) diatoms, (b) picophytoplankton, (c) nanoflagellates and (d) dinoflagellates to total chlorophyll $a$ (Chl $a$ ) concentration (calculated by CHEMTAX) as a function of their contribution to total carbon biomass (calculated from biovolume, see Materials and methods). The dashed line represents a $1: 1$ relationship. The Pearson correlation coefficient $\left(r^{2}\right)$ is indicated for each algal group. The root-mean-square error (RMSE) depicts the predictive capabilities of carbon biomass from the CHEMTAX derived algal groups. In total, $95 \%$ of the algal carbon biomass estimated from the CHEMTAX derived algal groups is in the range $\pm 2 \times$ RMSE from the least-squares regression line.

Heterotrophic dinoflagellates would only contain diagnostic pigments if they ingested them from their prey. It is known that heterotrophic and mixotrophic dinoflagellates feed on diverse types of prey including bacteria, picoeukaryotes, nanoflagellates, diatoms, other dinoflagellates, heterotrophic protists and metazoans due to their diverse feeding mechanisms (Jeong et al., 2010) and are likely to be significant consumers of bloom-forming diatoms (Sherr and Sherr, 2007). It follows that the presence of heterotrophic dinoflagellates could potentially lead to overestimation of the phytoplanktonic groups they ingest when looking at the pigment concentrations. In contrast to the study of (Brugel et al., 2009) in the Beaufort Sea during summer 2002, when autotrophic dinoflagellates contributed as much as heterotrophic dinoflagellates abundance, heterotrophic dinoflagellates were largely dominant in 2009. Strict autotrophic dinoflagellates represented only $13 \%$ of total dinoflagellate biomass.

The high contribution of heterotrophic dinoflagellates and ciliates in surface waters suggest an important transfer of organic material to the pelagic food web and a reduced sinking export of high-quality algal material, due to assimilation and remineralization as mentioned by Juul-Pedersen et al. (2010). This scenario also agrees with the observation of Forest et al. (2014), showing a limited vertical exchange of nutrients and carbon between the surface and subsurface and the establishment of a food web exclusively based on small protists using recycled nutrients. Conversely, the high abundance of centric diatoms at the SCM on the shelf could lead to an effective transfer of high-quality algal material to the benthos as evidenced by the very large pool and fluxes of particulate organic carbon (POC) observed at shelf stations by Forest et al. (2014) during the same cruise. The high abundance of Fuco previously observed in the sediment of the Mackenzie shelf during summer supports the hypothesis of an efficient export of diatoms to the seafloor (Morata et al., 2008).

\section{Conclusions}

We evaluated the utility of CHEMTAX to characterize phytoplankton dynamics in the Beaufort Sea in late summer 2009. Based on the taxonomic information from optical microscopy, a ratio matrix was created specifically for the Beaufort Sea and run using the CHEMTAX software.

The interpretation of the pigment data by CHEMTAX highlights linkages between the phytoplankton distribution and environmental parameters commonly observed in the Arctic Ocean. The productive and nutrient rich subsurface waters of the shelf were dominated (95\% of abundance) by the centric diatom identified by microscopy to be Chaetoceros socialis. In contrast, oligotrophic, nutrient-depleted surface waters over the shelf and basin constitute the highest amounts of green algae ( $48 \%$ of the TChl $a$ ), dominated by the pico-prasinophytes Micromonas sp.

The use of pigments and CHEMTAX also revealed more subtle information difficult to observe with other taxonomic methods. Indeed, two populations of flagellates were highlighted in subsurface waters of the basin: prymnesiophytes, rich in Hex-Fuco pigment, and a group of various flagellates rich in $\mathrm{Chl} c_{3}$ and Fuco (i.e., $c_{3}$-flagellates). The prymnesiophytes dominated where the subsurface chlorophyll maximum was located above $60 \mathrm{~m}$ and were associated with higher light availability and lower nutrient concentrations. In contrast, the $c_{3}$-flagellates dominated when the subsurface chlorophyll maximum was deeper than $60 \mathrm{~m}$ and the organisms were exposed to higher nitrate concentrations and lower light availability. Flagellate populations that are able to grow at deep subsurface chlorophyll $a$ maxima should be closely monitored in a context of a deepening nutricline observed over the past decade in the Canadian Arctic due to increased surface freshening and stratification.

The present study underlines the high sensitivity of CHEMTAX to the initial matrix ratio chosen and the misinterpretation introduced by the blind use of a ratio matrix calibrated in regions other than the targeted one. Therefore, we recommend that future pigment studies in the Beaufort Sea use the CHEMTAX parameterization developed in the present work. 
However, some issues and inconsistences should be considered when using CHEMTAX in the Beaufort Sea and, probably, in the entire Arctic Ocean. Despite high biomasses, the heterotrophic dinoflagellates of the Gymnodinium/Gyrodinium complex were undetected by pigment analyses since they lack peridinin. High heterotrophy can lead to misinterpretation because CHEMTAX potentially takes into account other pigments present in the algae ingested by dinoflagellates. Additionally, CHEMTAX underestimates the importance of small phytoplankton in terms of cell abundance but overestimates their importance in terms of carbon biomass. The variability in pigment content per cell and in the $\mathrm{C} / \mathrm{TChl} a$ ratio makes it difficult to relate pigment signatures to carbon biomass or cell abundance. The contribution of small phytoplankton to TChl $a$ was 2 to 3 times higher than their contribution to carbon biomass due to generally low C / TChl $a$ ratios of these organisms. The opposite was observed for large phytoplankton like dinoflagellates for which contribution to total biomass was higher than their contribution to TChl $a$. Overall, we found the contribution of algal groups to TChl $a$ (CHEMTAX) showed better agreement with their contribution to total cell abundance than their contribution to the total phytoplankton carbon biomass.

In contrast, for localized use of CHEMTAX, as presented in our study, the large pigment data set in the Arctic Ocean could be used to determine average pigment ratios for the dominant Arctic phytoplankton groups and create a single pan-Arctic ratio matrix for CHEMTAX. With this goal in mind, we recommend the creation of a simple ratio matrix in CHEMTAX to retrieve the three functional groups, diatoms, nanoflagellates and picophytoplankton, successfully validated by optical microscopy. Indeed, weak or no correlation was found between CHEMTAX and microscopy for the other groups: chrysophytes, prymnesiophytes, chlorophytes and cryptophytes. Nonetheless, we attribute these dissimilarities to the high proportion of flagellates that are unidentified or overlooked by microscopy rather than a misinterpretation by CHEMTAX.

Alternatively, when taxonomic information is lacking in the targeted study area, we recommend using the raw pigment data and selecting key pigment ratios rather than using a CHEMTAX parameterization tuned for a different region. The high reproducibility of the HPLC method for pigment measurements and a local CHEMTAX calibration would provide a suitable approach to detect interannual changes in the phytoplankton communities. Nevertheless, pigment-derived information gains in accuracy when coupled with other measurement types. The optical microscopy and flow cytometry remain crucial to convert the phytoplankton into carbon budget or to detect heterotrophic plankton groups such as the dinoflagellates.

The Supplement related to this article is available online at doi:10.5194/bg-12-991-2015-supplement.
Acknowledgements. This study was conducted as part of the Malina Scientific Program led by Marcel Babin and funded by ANR (Agence nationale de la recherche), INSU-CNRS (Institut national des sciences de l'Univers - Centre national de la recherche scientifique), CNES (Centre national d'études spatiales) and the ESA (European Space Agency). The present study started at the LOCEAN laboratory (UPMC - University Pierre et Marie Curie), supported by the Arctic Tipping Point project (ATP, http://www.eu-atp.org), funded by FP7 of the European Union (contract \#226248) and was continued at Laval University (Quebec, Canada), funded by the Canada Excellence Research Chair in "Remote sensing of Canada's new Arctic frontier" and QuébecOcéan. We are grateful to the crew and captain of the Canadian research icebreaker CCGS Amundsen. Thanks to S. Lessard for the phytoplankton identification and enumeration by light microscopy and to J. Ras for pigment analysis.

Edited by: E. Boss

\section{References}

Alou-Font, E., Mundy, C. J., Roy, S., Gosselin, M., and Agustí, S.: Snow cover affects ice algal pigment composition in the coastal Arctic Ocean during spring, Mar. Ecol.-Prog. Ser., 474, 89-104, 2013.

Alvain, S., Moulin, C., Dandonneau, Y., and Breon, F. M.: Remote sensing of phytoplankton groups in case 1 waters from global SeaWiFS imagery, Deep-Sea Res. Pt. I, 52, 1989-2004, 2005.

Ansotegui, A., Trigueros, J., and Orive, E.: The use of pigment signatures to assess phytoplankton assemblage structure in estuarine waters, Estuar. Coast. Shelf. S., 52, 689-703, 2001.

Balzano, S., Marie, D., Gourvil, P., and Vaulot, D.: Composition of the summer photosynthetic pico and nanoplankton communities in the Beaufort Sea assessed by T-RFLP and sequences of the 18S rRNA gene from flow cytometry sorted samples, ISME J., 6 , 1480-1498, 2012.

Bérard-Therriault, L., Poulin, M., and Bossé, L.: Guide d'identification du phytoplancton marin de l'estuaire et du golfe du Saint-Laurent: incluant également certains protozoaires, Publ. spéc. can. sci. halieut. aquat., 1999 (in French).

Bidigare, R. R., Frank, T. J., Zastrow, C., and Brooks, J. M.: The distribution of algal chlorophylls and their degradation products in the Southern Ocean, Deep-Sea. Res., 33, 923-937, 1986.

Booth, B. C., Larouche, P., Bélanger, S., Klein, B., Amiel, D., and Mei, Z. P.: Dynamics of Chaetoceros socialis blooms in the North Water, Deep-Sea. Res. Pt. II, 49, 5003-5025, 2002.

Brugel, S., Nozais, C., Poulin, M., Tremblay, J. E., Miller, L. A., Simpson, K. G., Gratton, Y., and Demers, S.: Phytoplankton biomass and production in the southeastern Beaufort Sea in autumn 2002 and 2003, Mar. Ecol.-Prog. Ser., 377, 63-77, 2009.

Carmack, E. and Wassmann, P.: Food webs and physical-biological coupling on pan-Arctic shelves: unifying concepts and comprehensive perspectives, Prog. Oceanogr., 71, 446-477, 2006.

Carmack, E. C., Macdonald, R. W., and Jasper, S.: Phytoplankton productivity on the Canadian Shelf of the Beaufort Sea, Mar. Ecol.-Prog. Ser., 277, 37-50, 2004.

Comeau, A. M., Li, W. K., Tremblay, J. E., Carmack, E. C., and Lovejoy, C.: Arctic Ocean microbial community structure be- 
fore and after the 2007 record sea ice minimum, PLoS ONE, 6, e27492, doi:10.1371/journal.pone.0027492, 2011.

Comiso, J. C., Parkinson, C. L., Gersten, R., and Stock, L.: Accelerated decline in the Arctic sea ice cover, Geophys. Res. Lett., 35, L01703, doi:10.1029/2007GL031972, 2008.

Coupel, P., Jin, H. Y., Joo, M., Horner, R., Bouvet, H. A., Sicre, M. A., Gascard, J. C., Chen, J. F., Garçon, V., and RuizPino, D.: Phytoplankton distribution in unusually low sea ice cover over the Pacific Arctic, Biogeosciences, 9, 4835-4850, doi:10.5194/bg-9-4835-2012, 2012.

Del Campo, J. A., Moreno, J., Rodriguez, H., Vargas, M. A., Rivas, J., and Guerrero, M. G.: Carotenoid content of chlorophycean microalgae: factors determining lutein accumulation in Muriellopsis sp. (Chlorophyta), J. Biotechnol., 76, 51-59, 2000.

Demers, S., Roy, S., Gagnon, R., and Vignault, C.: Rapid light-induced-changes in cell fluorescence and in xanthophyllcycle pigments of Alexandrium-Excavatum (dinophyceae) and thalassiosira-pseudonana (bacillariophyceae) - a photoprotection mechanism, Mar. Ecol.-Prog. Ser., 76, 185-193, 1991.

Falkowski, P.: The global carbon cycle: a test of our knowledge of earth as a system, Science, 290, 291-296, 2000.

Forest, A., Coupel, P., Else, B., Nahavandian, S., Lansard, B., Raimbault, P., Papakyriakou, T., Gratton, Y., Fortier, L., Tremblay, J.-É., and Babin, M.: Synoptic evaluation of carbon cycling in Beaufort Sea during summer: contrasting river inputs, ecosystem metabolism and air-sea $\mathrm{CO}_{2}$ fluxes, Biogeosciences, 11, 28272856, doi:10.5194/bg-11-2827-2014, 2014.

Frank, H. A., Cua, A., Chynwat, V., Young, A., Gosztola, D., and Wasielewski, M. R.: Photophysics of the carotenoids associated with the xanthophyll cycle in photosynthesis, Photosynth. Res., 41, 389-395, 1994.

Fujiki, T. and Taguchi, S.: Variability in chlorophyll a specific absorption coefficient in marine phytoplankton as a function of cell size and irradiance, J. Plankton Res., 24, 859-874, 2002.

Geider, R., Platt, T., and Raven, J. A.: Size dependence of growth and photosynthesis in diatoms: a synthesis, Mar. Ecol.-Prog. Ser, 30, 93-104, 1986.

Grebmeier, J. M., Moore, S. E., Overland, J. E., Frey, K. E., and Gradinger, R.: Biological response to recent Pacific Arctic Sea ice retreats, Eos T. Am. Geophys. Un. USA, 91, 161-168, 2010.

Higgins, H. W., Wright, S. W., and Schlüter, L.: Quantitative interpretation of chemotaxonomic pigment data, in: Phytoplankton Pigments: Characterization, Chemotaxonomy and Applications in Oceanography, edited by: Roy, S., Llewellyn, C. A., Egeland, E. S., and Johnsen, G., Cambridge University Press, UK, 257313, 2011.

Hill, V., Cota, G., and Stockwell, D.: Spring and summer phytoplankton communities in the Chukchi and Eastern Beaufort Seas, Deep-Sea Res. Pt. II, 52, 3369-3385, 2005.

Hirata, T., Hardman-Mountford, N. J., Brewin, R. J. W., Aiken, J., Barlow, R., Suzuki, K., Isada, T., Howell, E., Hashioka, T., Noguchi-Aita, M., and Yamanaka, Y.: Synoptic relationships between surface Chlorophyll- $a$ and diagnostic pigments specific to phytoplankton functional types, Biogeosciences, 8, 311-327, doi:10.5194/bg-8-311-2011, 2011.

Hooker, S. B., Van Heukelem, L., Thomas, C. S., Claustre, H., Ras, J., Barlow, R., Sessions, H., Schlüter, L., Perl, J., and Trees,C.: Second SeaWiFS HPLC Analysis Round-robin Experiment (SeaHARRE-2), National Aeronautics and Space Admin- istration, Goddard Space Flight Center, Greenbelt, Maryland, 2005.

Hunt Jr., G. L., Stabeno, P., Walters, G., Sinclair, E., Brodeur, R. D., Napp, J. M., and Bond, N. A.: Climate change and control of the southeastern Bering Sea pelagic ecosystem, Deep-Sea Res. Pt. II, 49, 5821-5853, 2002.

IOCCG: Phytoplankton Functional Types from Space, edited by: Sathyendranath, S., Reports of the International Ocean-Colour Coordinating Group, No. 15, IOCCG, Dartmouth, Canada, 2014.

Irigoien, X., Meyer, B., Harris, R., and Harbour, D.: Using HPLC pigment analysis to investigate phytoplankton taxonomy: the importance of knowing your species, Helgoland Mar. Res., 58, 7782, 2004.

Jeffrey, S. W., Mantoura, R. F. C., and Wright, S. W.: Phytoplankton pigments in oceanography, Monographs on oceanographic methods, UNESCO, Paris, 1997.

Jeong, H., Yoo, Y., Kim, J., Seong, K., Kang, N., and Kim, T.: Growth, feeding and ecological roles of the mixotrophic and heterotrophic dinoflagellates in marine planktonic food webs, Ocean Science Journal, 45, 65-91, 2010.

Juul-Pedersen, T., Michel, C., and Gosselin, M.: Sinking export of particulate organic material from the euphotic zone in the eastern Beaufort Sea, Mar. Ecol.-Prog. Ser., 410, 55-70, 2010.

Kozlowski, W. A., Deutschman, D., Garibotti, I., Trees, C., and Vernet, M.: An evaluation of the application of CHEMTAX to Antarctic coastal pigment data, Deep-Sea Res. Pt. I, 58, 350364, 2011.

Lewitus, A. J., White, D. L., Tymowski, R. G., Geesey, M. E., Hymel, S. N., and Noble, P. A.: Adapting the CHEMTAX method for assessing phytoplankton taxonomic composition in southeastern US estuaries, Estuaries, 28, 160-172, 2005.

Li, W. K., McLaughlin, F. A., Lovejoy, C., and Carmack, E. C.: Smallest algae thrive as the Arctic Ocean freshens, Science, 326, p. 539, 2009.

Lovejoy, C., Vincent, W. F., Bonilla, S., Roy, S., Martineau, M.-J., Terrado, R., Potvin, M., Massana, R., and Pedrós-Alió, C.: Distribution, phylogeny, and growth of cold-adapted picoprasinophytes in Arctic seas, J. Phycol., 43, 78-89, 2007.

Lund, J. W. G., Kipling, C., and Cren, E. D.: The inverted microscope method of estimating algal numbers and the statistical basis of estimations by counting, Hydrobiologia, 11, 143-170, 1958.

Mackey, M. D., Mackey, D. J., Higgins, H. W., and Wright, S. W.: CHEMTAX - a program for estimating class abundances from chemical markers: application to HPLC measurements of phytoplankton, Mar. Ecol.-Prog. Ser., 144, 265-283, 1996.

MacQueen, J.: Some methods for classification and analysis of multivariate observations, in: Proceedings of the fifth Berkeley symposium on mathematical statistics and probability, 1, 281-297, 1967.

Marie, D., Partensky, F., Jacquet, S., and Vaulot, D.: Enumeration and cell cycle analysis of natural populations of marine picoplankton by flow cytometry using the nucleic acid stain SYBR Green I, Appl. Environ. Microb., 63, 186-193, 1997.

McLaughlin, F. A. and Carmack, E. C.: Deepening of the nutricline and chlorophyll maximum in the Canada Basin interior, 2003-2009, Geophys. Res. Lett., 37, L24602, doi:10.1029/2010GL045459, 2010. 
Menden-Deuer, S. and Lessard, E. J.: Carbon to volume relationships for dinoflagellates, diatoms, and other protist plankton, American Society of Limnology and Oceanography, Waco, Texas, USA, 2000.

Montagnes, D. J., Berges, J. A., Harrison, P. J., and Taylor, F.: Estimating carbon, nitrogen, protein, and chlorophyll $a$ from volume in marine phytoplankton, Limnol. Oceanogr., 39, 1044-1060, 1994.

Morata, N., Renaud, P. E., Brugel, S., Hobson, K. A., and Johnson, B. J.: Spatial and seasonal variations in the pelagic-benthic coupling of the southeastern Beaufort Sea revealed by sedimentary biomarkers, Mar. Ecol.-Prog. Ser., 371, 47-63, 2008.

Not, F., Ramon, M., Latasa, M., Marie, D., Colson, C., Eikrem, W., Pedrós-Alió, C., Vaulot, D., and Simon, N.: Late Summer Community Composition and Abundance of Photosynthetic Picoeukaryotes in Norwegian and Barents Seas, Limnol. Oceanogr., 50, 1677-1686, 2005.

Olenina, I., Hajdu, S., Edler, L., Andersson, A., Wasmund, N., Busch, S., Göbel, J., Gromisz, S., Huseby, S., Huttunen, M., Jaanus, A., Kokkonen, P., Ledaine, I., and Niemkiewicz, E.: Biovolumes and size-classes of phytoplankton in the Baltic Sea, Baltic Marine Environment Protection Commission - HELCOM, Helsinki, 2006.

Pickart, R. S., Schulze, L. M., Moore, G. W. K., Charette, M. A., Arrigo, K. R., van Dijken, G., and Danielson, S. L.: Long-term trends of upwelling and impacts on primary productivity in the Alaskan Beaufort Sea, Deep-Sea Res. Pt. I, 79, 106-121, 2013.

Poulin, M., Daugbjerg, N., Gradinger, R., Ilyash, L., Ratkova,T., and Quillfeldt, C.: The pan-Arctic biodiversity of marine pelagic and sea-ice unicellular eukaryotes: a first-attempt assessment, Marine Biodiversity, 41, 13-28, 2010.

Riegman, R. and Kraay, G. W.: Phytoplankton community structure derived from HPLC analysis of pigments in the Faroe-Shetland Channel during summer 1999: the distribution of taxonomic groups in relation to physical/chemical conditions in the photic zone, J. Plankton Res., 23, 191-205, 2001.

Rodriguez, F., Varela, M., and Zapata, M.: Phytoplankton assemblages in the Gerlache and Bransfield Straits (Antarctic Peninsula) determined by light microscopy and CHEMTAX analysis of HPLC pigment data, Deep-Sea. Res. Pt. II, 49, 723-747, 2002.

Rothrock, D. A., Yu, Y., and Maykut, G. A.: Thinning of the Arctic sea-ice cover, Geophys. Res. Lett., 26, 3469-3472, 1999.

Roy, S., Chanut, J.-P., Gosselin, M., and Sime-Ngando, T.: Characterization of phytoplankton communities in the lower St. Lawrence Estuary using HPLC-detected pigments and cell microscopy, Mar. Ecol.-Prog. Ser., 142, 55-73, 1996.

Sathyendranath, S., Watts, L., Devred, E., Platt, T., Caverhill, C., and Maass, H.: Discrimination of diatoms from other phytoplankton using ocean-colour data, Mar. Ecol.-Prog. Ser., 272, 59-68, 2004.

Schlüter, L., Møhlenberg, F., Havskum, H., and Larsen, S.: The use of phytoplankton pigments for identifying and quantifying phytoplankton groups in coastal areas: testing the influence of light and nutrients on pigment/chlorophyll a ratios, Mar. Ecol.-Prog. Ser., 192, 49-63, 2000.

Sherr, E. B. and Sherr, B. F.: Heterotrophic dinoflagellates: a significant component of microzooplankton biomass and major grazers of diatoms in the sea, Mar. Ecol.-Prog. Ser., 352, 187-197, doi:10.3354/meps07161, 2007.
Sigman, D. M. and Boyle, E. A.: Glacial/interglacial variations in atmospheric carbon dioxide, Nature, 407, 859-869, 2000.

Stroeve, J. C., Serreze, M. C., Holland, M. M., Kay, J. E., Malanik, J., and Barrett, A. P.: The Arctic's rapidly shrinking sea ice cover: a research synthesis, Climatic Change, 110, 1005-1027, 2011.

Suzuki, K., Minami, C., Liu, H., and Saino, T.: Temporal and spatial patterns of chemotaxonomic algal pigments in the subarctic Pacific and the Bering Sea during the early summer of 1999 , Deep-Sea. Res. Pt. II, 49, 5685-5704, 2002.

Taylor, R. L., Semeniuk, D. M., Payne, C. D., Zhou, J., Tremblay, J.-É., Cullen, J. T., and Maldonado, M. T.: Colimitation by light, nitrate, and iron in the Beaufort Sea in late summer, J. Geophys. Res.-Oceans, 118, 3260-3277, 2013.

Tremblay, J. E., Belanger, S., Barber, D. G., Asplin, M., Martin, J., Darnis, G., Fortier, L., Gratton, Y., Link, H., Archambault, P., Sallon, A., Michel, C., Williams, W. J., Philippe, B., and Gosselin, M.: Climate forcing multiplies biological productivity in the coastal Arctic Ocean, Geophys. Res. Lett., 38, L18604, doi:10.1029/2011GL048825, 2011.

Uitz, J., Claustre, H., Morel, A., and Hooker, S. B.: Vertical distribution of phytoplankton communities in open ocean: an assessment based on surface chlorophyll, J. Geophys. Res., 111, doi:10.1029/2005JC003207, 2006.

Van den Hoek, C., Mann, D. G., and Jahns, H. M.: Algae: an introduction to phycology, Cambridge University Press, Cambridge, UK, 1995.

Van Heukelem, L. and Thomas, C. S.: Computer-assisted highperformance liquid chromatography method development with applications to the isolation and analysis of phytoplankton pigments, J. Chromatogr. A, 910, 31-49, 2001.

Vidussi, F., Roy, S., Lovejoy, C., Gammelgaard, M., Thomsen, H., Booth, B., Tremblay, J. E., and Mostajir, B.: Spatial and temporal variability of the phytoplankton community structure in the North Water Polynya, investigated using pigment biomarkers, Can. J. Fish. Aquat. Sci., 61, 2038-2052, 2004.

von Quillfeldt, C. H.: Common Diatom Species in Arctic Spring Blooms: Their Distribution and Abundance, Bot. Mar., 46, 499516, doi:10.1515/BOT.2000.050, 2000.

Wassmann, P. and Reigstad, M.: Future arctic ocean seasonal ice zones and implications for pelagic-benthic coupling, Oceanography, 24, 220-231, 2011.

Wassmann, P., Duarte, C. M., Agusti, S., and Sejr, M. K.: Footprints of climate change in the Arctic marine ecosystem, Glob. Change Biol., 17, 1235-1249, 2011.

Wright, S. W. and Jeffrey, S. W.: Pigment Markers for Phytoplankton Production, in: Marine Organic Matter: Biomarkers, Isotopes and DNA, edited by: Volkman, J., The Handbook of Environmental Chemistry, Springer Berlin Heidelberg, 2006.

Wright, S. W., Thomas, D. P., Marchant, H. J., Higgins, H. W., Mackey, M. D., and Mackey, D. J.: Analysis of phytoplankton of the Australian sector of the Southern Ocean: comparisons of microscopy and size frequency data with interpretations of pigment HPLC data using the "CHEMTAX" matrix factorisation program, Mar. Ecol.-Prog. Ser., 144, 285-298, 1996. 